\title{
الحرب الأعلانية الألكتزونية بين الشركات التجارية العالمية
}

أ.م. د هدى مالك شبيب

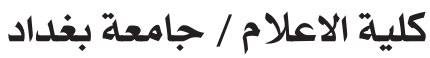

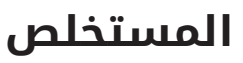

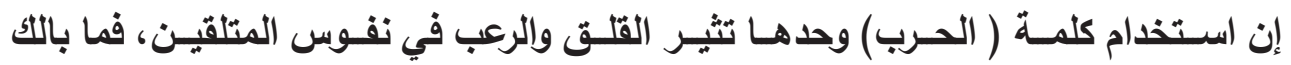

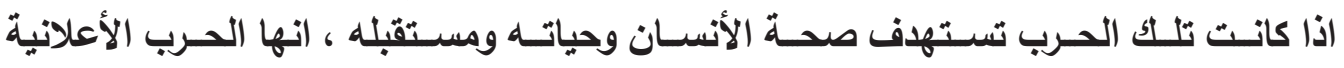

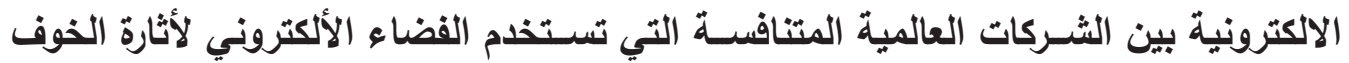

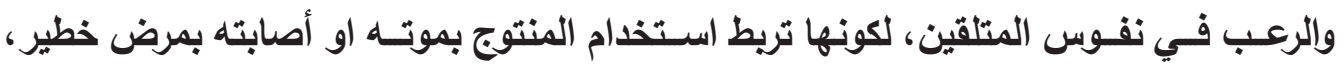

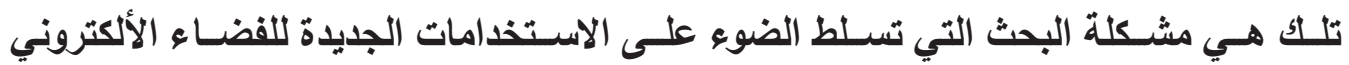

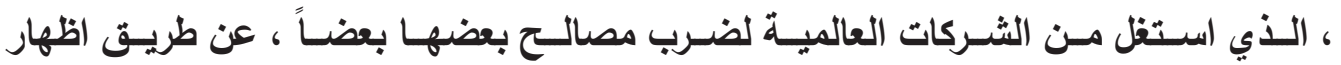

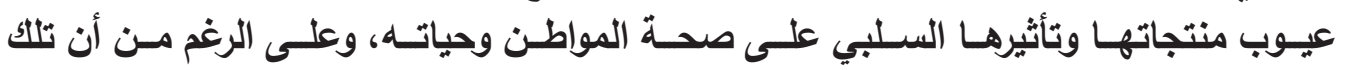

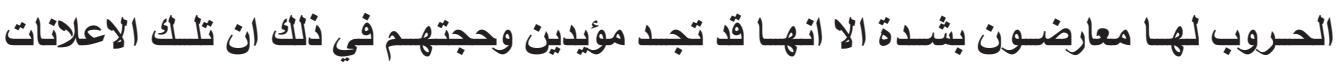

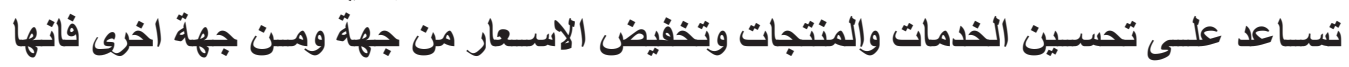

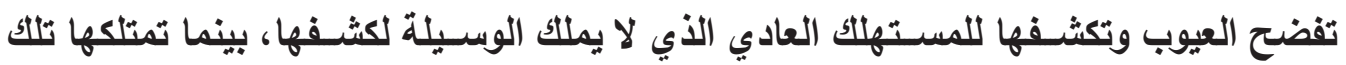

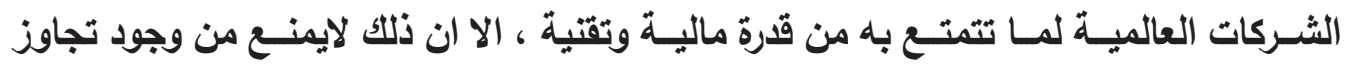

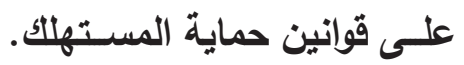

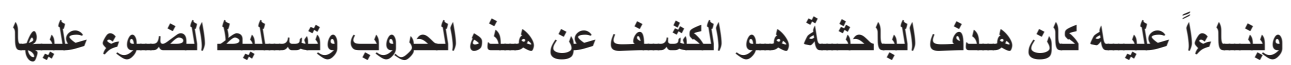

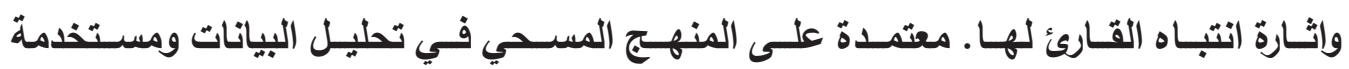

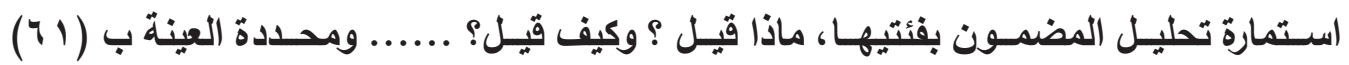

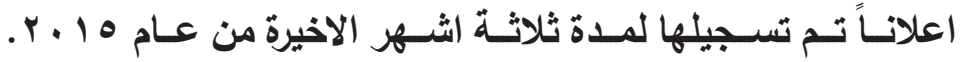

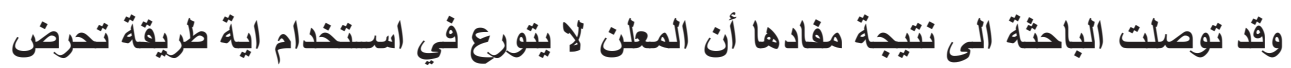

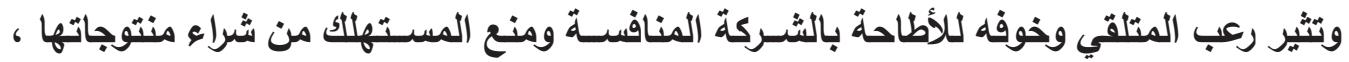

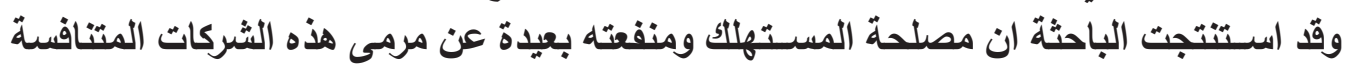




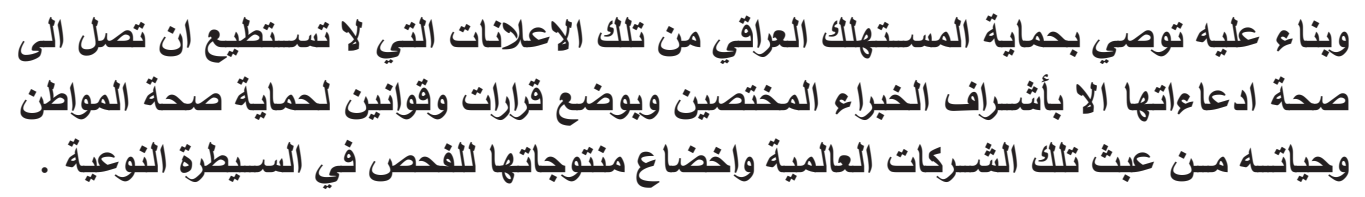

\section{The Electronic Advertising War among Commercial Companies Assistant Professor Huda Malik University of Baghdad/College of Media}

The use of the word "war" alone raises horror and fear in the hearts of the recipients, especially if this war aimed at human's life, his health and his future. It is the electronic advertising war among rival international companies that use cyberspace to create fear and horror in the hearts of the recipients because it connects the use of the product with human's death or serious illness.

The problem of this research sheds light on the new uses of cyberspace which fucked by international companies to strike the interests of each other by displaying the defects of their products and its negative impact on citizen's life. Despite the fact that those wars have opposed strongly, there are supporters for those wars. Their argument is that those advertisements help to improve the products and services, reduce their prices on one hand, and on the other, it exposes the flaws to the normal users who does not have the means to detect them while international companies have these means due to their technical and physical capabilities. But that has not prevented the existence of bypass consumer protection laws.

The aim of this research is to detect these wars highlight them and stir the readers 'attention depending on the survey method in analyzing the data and using content analysis form of both categories "what was said?" and "how it was said?". The sample is limited to 61 advertisements which was recorded for the last three months of 2015. The researcher concludes the following: 1-the advertiser does not hesitate to use any means in citing and provoking horror and fear of the recipients in order to oust the competitive company and prevent the consumers from buying its product.

2-the interest and utility of the consumer have no existence among these companies.

Therefore, the researcher recommends that the government must protect the Iraqi consumers from those ads since no one can check their truth claims only under the supervision of experts and specialists, legislate laws and resolutions to protect the citizen's life and his life of the futility of these global companies and subjecting their products for testing and quality control.

\begin{tabular}{l|c} 
& مجلة الباحث الاعلامي| \\
\hline 1. & العدد (r )
\end{tabular}




\section{المدخل}

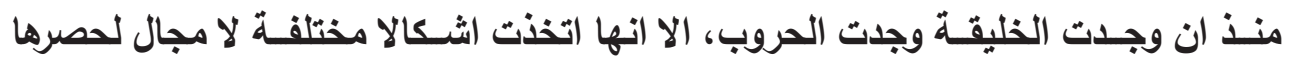

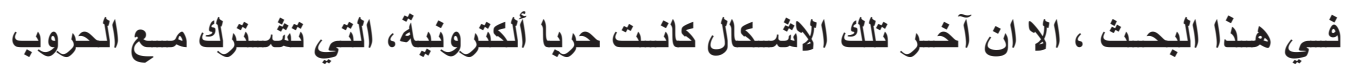

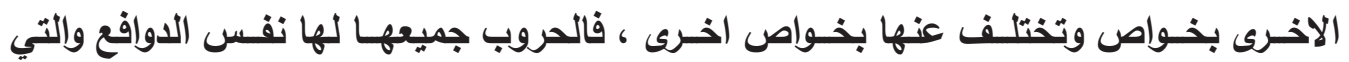

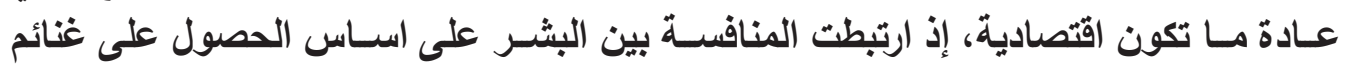

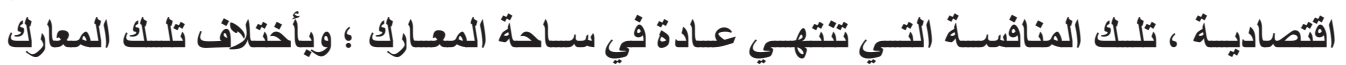

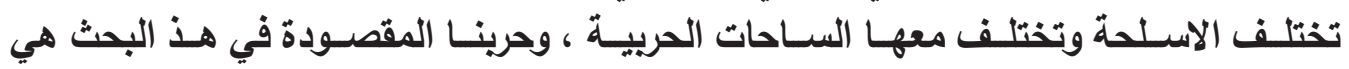

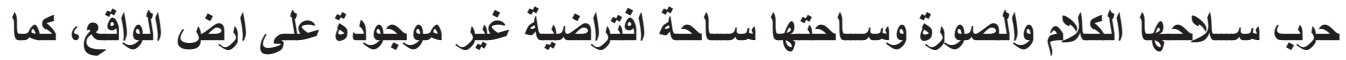

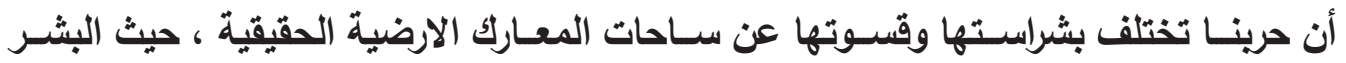

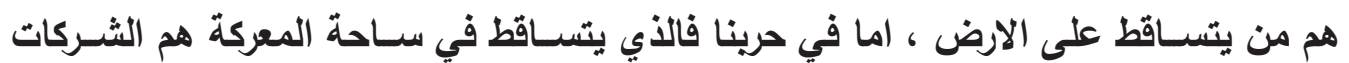

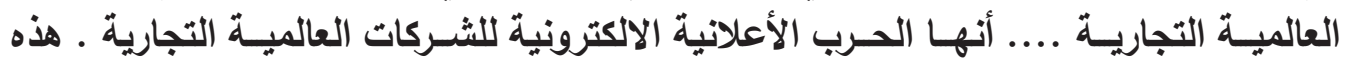

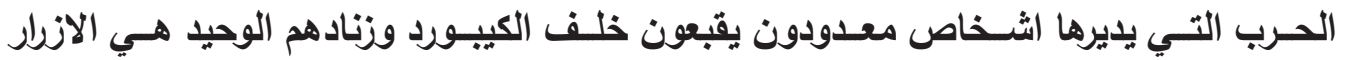

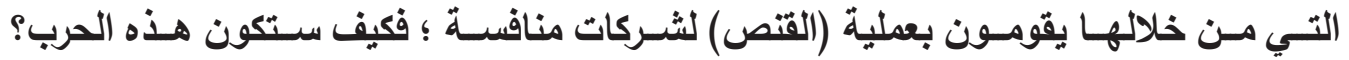

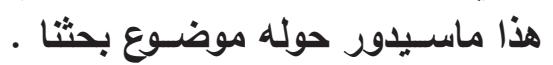

\section{الاطار المنهجي}

\section{1. مشكلة البحث}

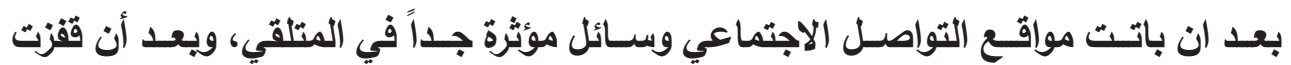

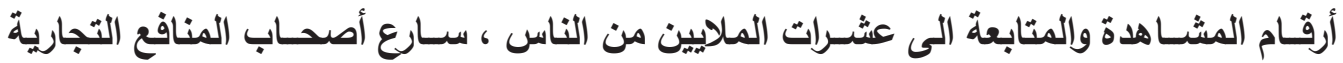

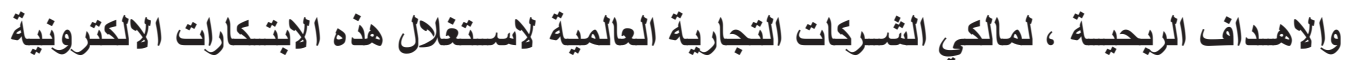

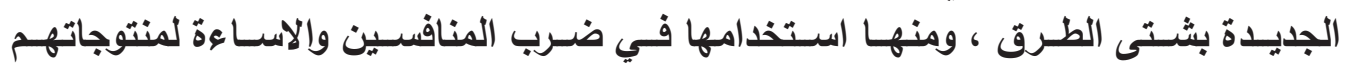

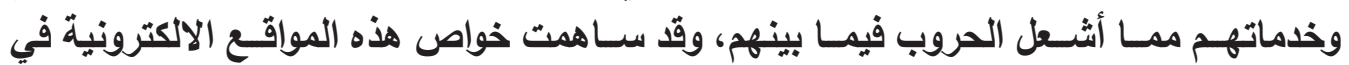

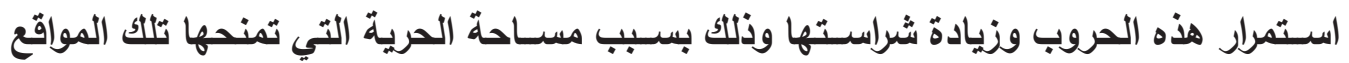

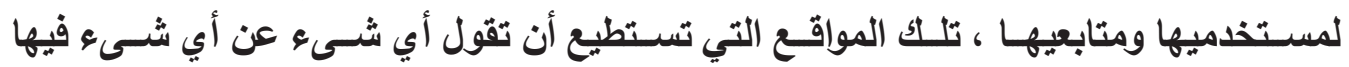

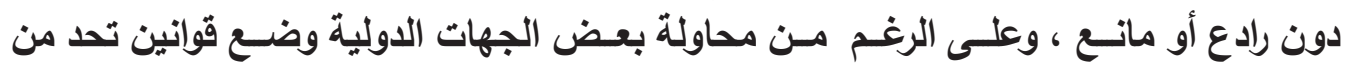

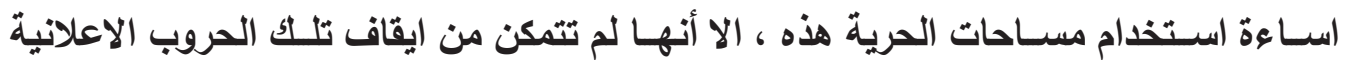

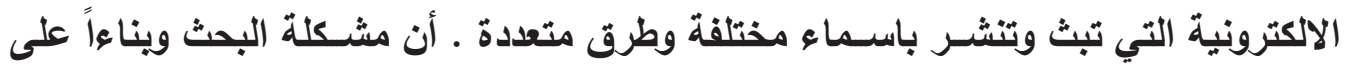

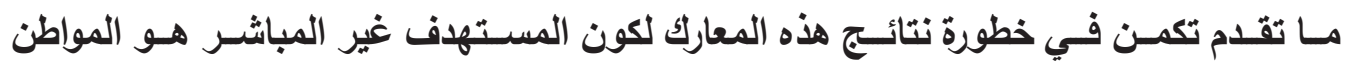

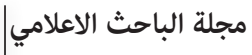


المسـتهلك البسـيط ـ وأن ظن البعض أن المستهذف هو الثـركات التجارية العالمية المنافسة،

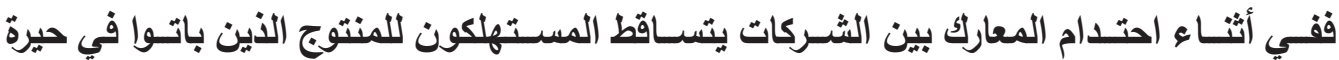

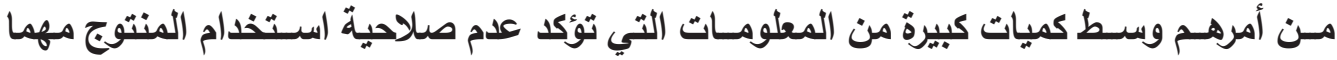

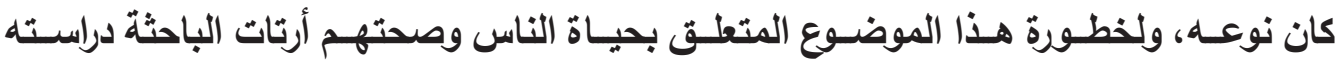

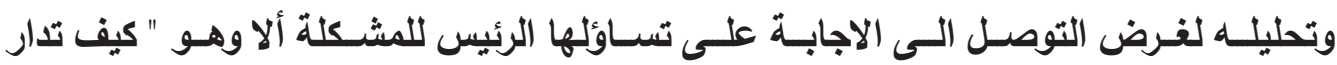

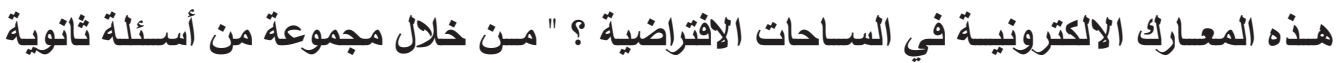
طرحتها الباحثة مسـتمدة من التســاؤل الرئيس ألا وهي: ا ـ ماذا تقول هذه الشركات في حربها الالكترونية ؟ r ـ ما الاساليب التي تستخدمها الشركات في حريها الالكترونية ؟ r. ما الأشكال والأنواع الاعلانية المستخدمة في تلك الحرب؟ ؛ .ما الحجج والبراهين التي تعتمدها تلك الثركات في حربها؟

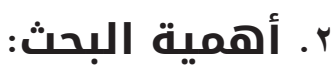

أن مـا أثـار انتبـاه الباحثـة هـو أن تلك الثــركات التي تجـاوزت حدود واخلاقيـات المهنة

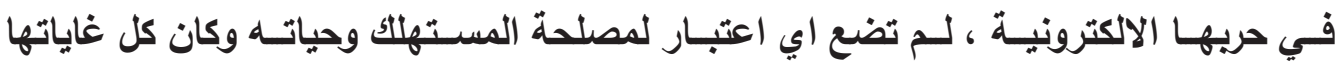

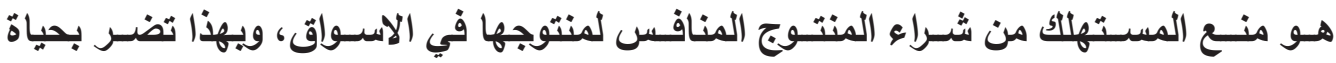

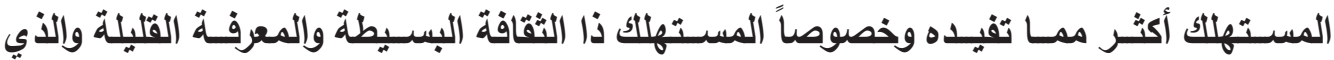

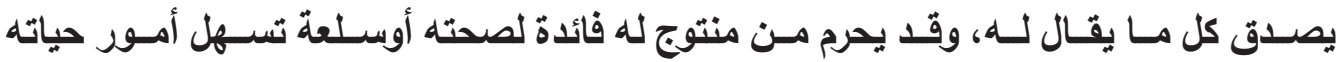

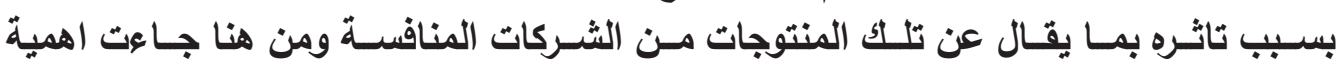
البحث العلميـة للمجتمع. r. أهداف البحث يهاف البحث الى معرفة طريقة ادارة الثـركات العالمية لحربها الأكترونية ضد منافسـيها،

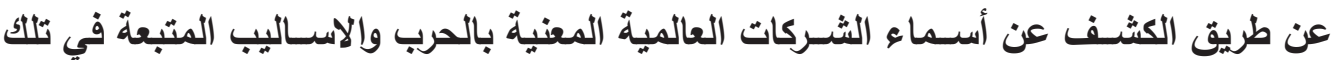

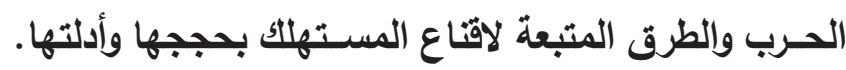
؛. منهج البحث وأدواته

اســخدمت الباحثـة المنهج المســي الـــي يعد احد انواع البحـوث الوصفية، معتمدة على

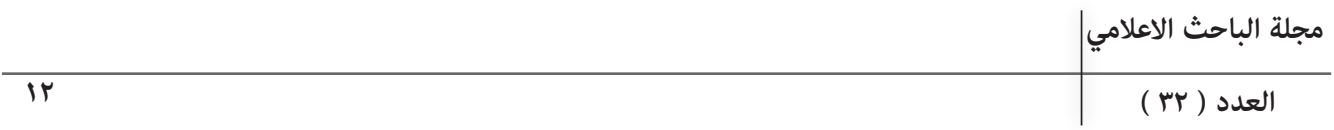




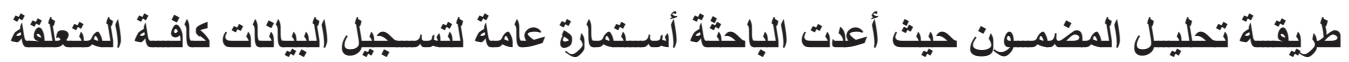

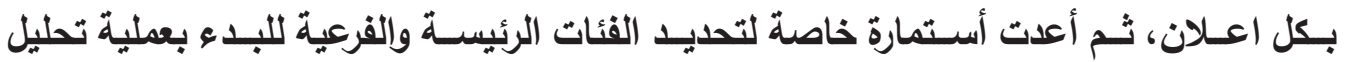

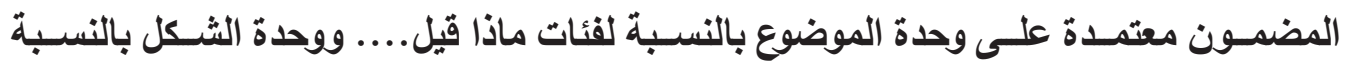

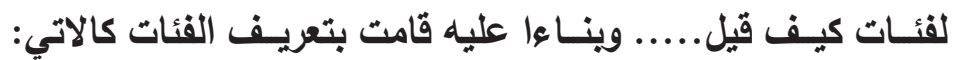

\section{الفئات الرئيسية وماتفرع منها ؟} الاساليب اللغوية: أ. الامر : استعمال افعال بصيغة الامر. ب. النهي: استعمال الفعل المضارع بصيغة النهي . ج. المدح والذم : استعمال كلمات التفضيل لمدح، وكلمات معاكسة للذأم د. التحذير. اسلوب يراد به تتبيه المخاطب لتجنب مكروهاً باستخدام كلمة (إحذر).(1).

\section{r. الاساليب الاقناعية العاطفية}

أ- التبكيث: استعمال اسلوب لتانيب الضمير والاحساس بالندم (ץ).

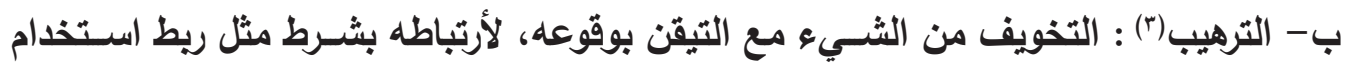
المنتوج بالموت.

ج- الصدمة: هو مفاجأة المتلقي بصورة او كلام ذي محتوى عنيف ومباشر. د - التخويف (؛): هو الخوف مع الثكك بوقوعه , اي تخويف المتلقي من دون اعطاء الدليل.

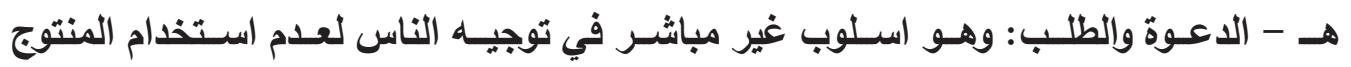
بصيغـة دعـوة او طلب.

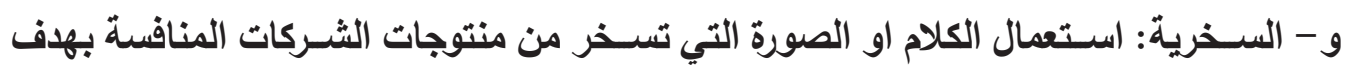
التقليـل من أهمية المنتوج. ز - نصائح وارشادات : حث الناس على عدم استعمال المنتوج بطريقة النصح والارشاد.

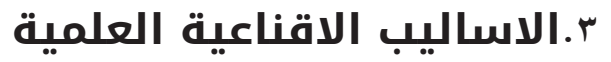

أ. الحججوالبراهين : يعطي المعلن أدلة على خطورة أستخدام المنتوجوتكون معززةبالتجريةوالصور

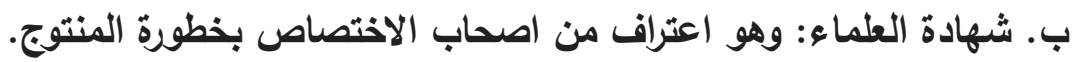
ج. الارقام والرموز : احصائيات ورموز لغوية تؤكد خطورة المن النتوج.

\begin{tabular}{l|c} 
& مجلة الباحث الاعلامي| \\
\hline$\mu$ & العدد ( $1 \%$
\end{tabular}




\section{؛.الاسس التي اعتمدتها الحرب في توجيه اعلاناتها.} أ. دينية:- توظيف المعتقات الدينية. ب.صحيه:- توظيف المخاوف من الامراض والموت. ج. أجتماعية:- توظيف العرف الاجتماعي. ه. الأساليب الفنية المسموعة

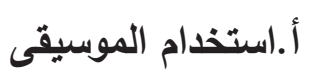

ب.اسـتخدام المؤثترات الصوتيـة: صـوت أسـتخدام المنتـوج أو صوت الطبيعـة أو اي أصوات

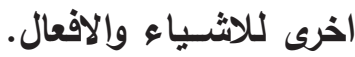
ج.بدون استخام اي مؤثرات او موسيقى

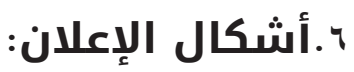
ا ـ آيقوني : صورة المنتوج بدون كلام. r ب نصي : كلام نصي بدون صورة

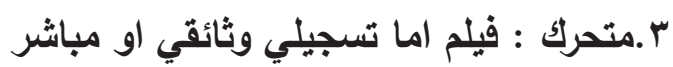

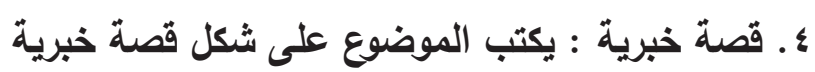
ه. تمثيلي: اداء تمثيلي لتبيان مساويء المنتوج. آ. ايقوني نصي: يجمع الإعلان بين صورة المنتوج والخبر.

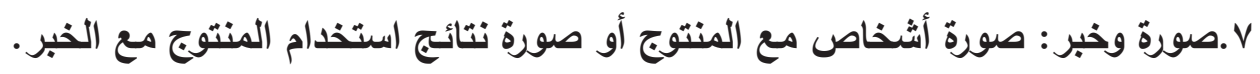
ه. حدود البحث ومجالاته:

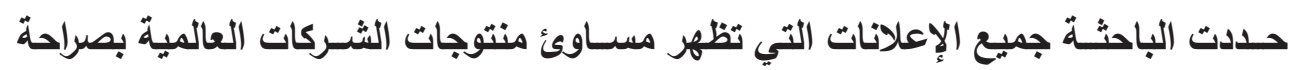

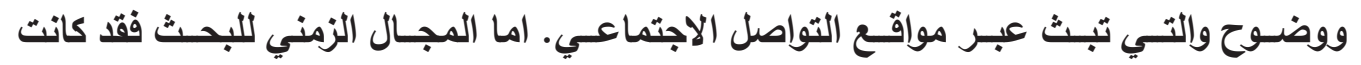

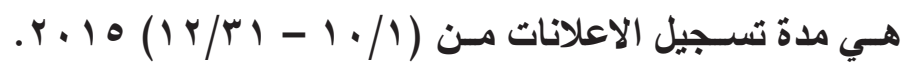

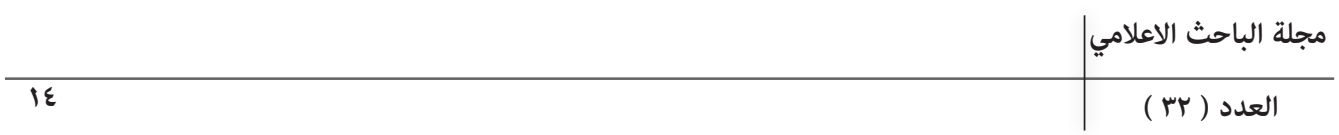


צ.

حصرت الباحثة عينتها، بمدة تسـجيل البحث حصراً شـاملا لمدة ثلاثة اشـهر ، وقد بلغت إثلت العينة (1) آ العلاناً.

\section{v. دراسات و آراء سابقة عن الحرب الإعلانية الالكترونية}

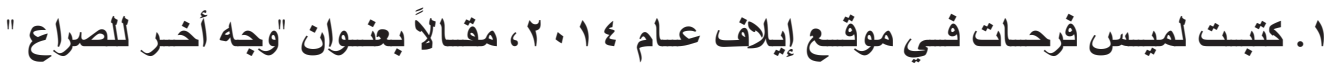

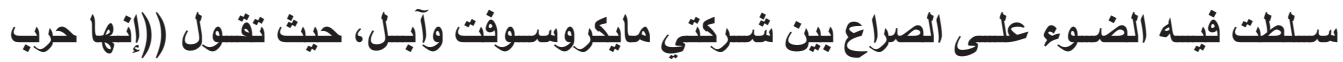

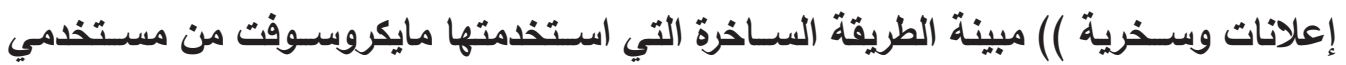

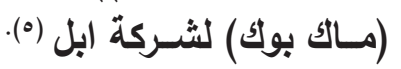

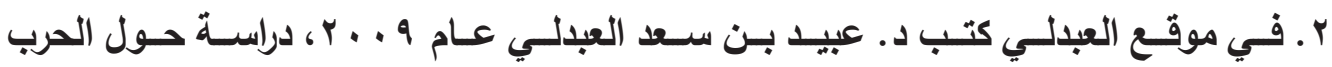

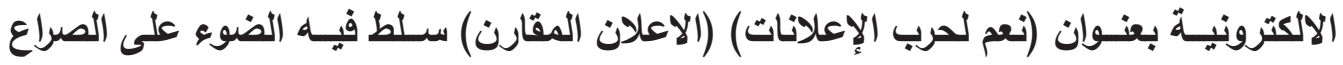

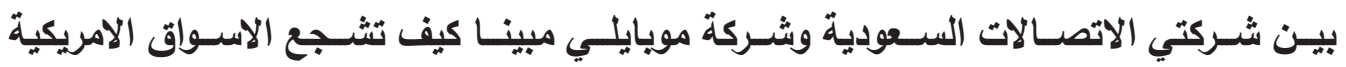

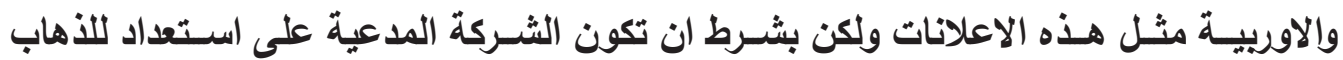

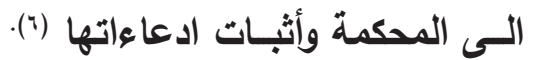

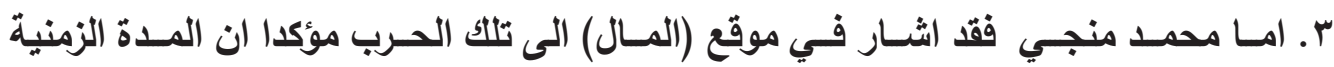

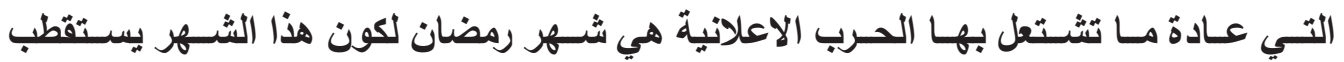

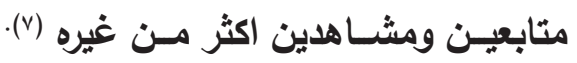

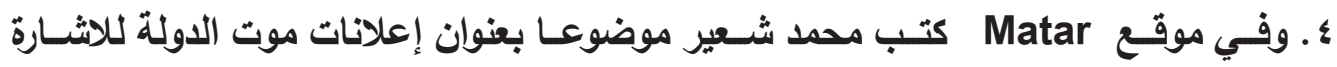

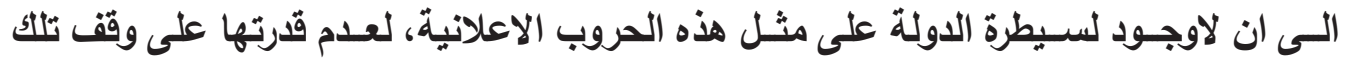

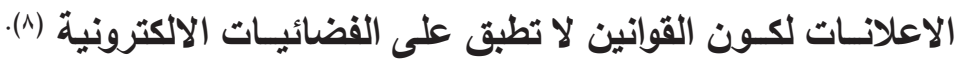
^. المفاهيم والمصطلحات المتعلقة بموضوع البحث:

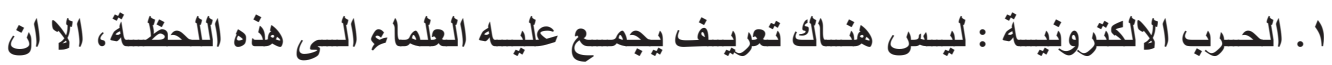

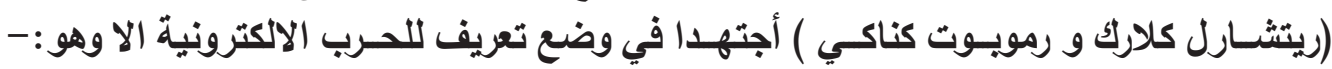
( أعمـال تقـوم بهـا دولة تحاول من خلالها أختـرلق أجهزة الكمبيوتز والثــبكات التابعة لدولة

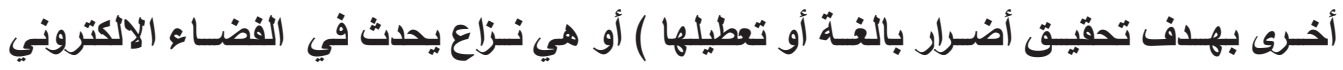

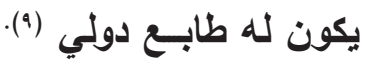

مجلة الباحث الاعلامي| - مجي 
r ـ الثــركات التجاريـة : هي الثــركات التي تهتــم بجميع فروع القطاع الاقتصــادي وتقوم بكل

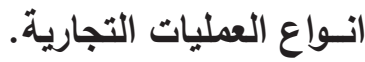

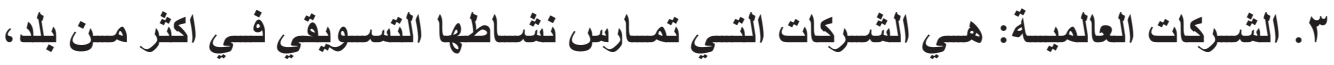

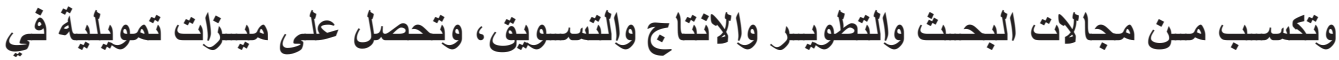

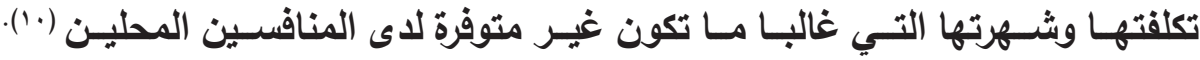

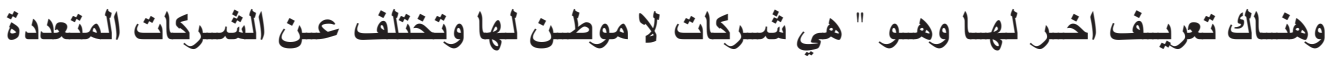

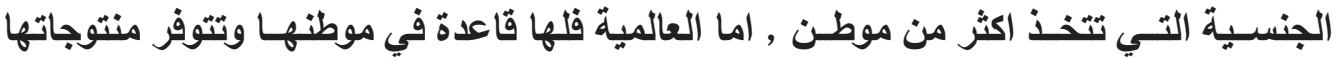
في كل الاسـواق العالمية (11). ع. الأساليب العاطفية:

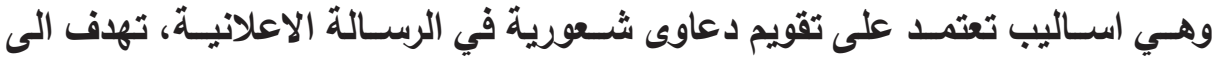
التاثير في وجدان المتلقي وإنفعالاته واثثارة حاجاته النفسية والاجتماعية ومخاطبة حواسله (ז'). ه. الاساليب العلمية والعقلانية:

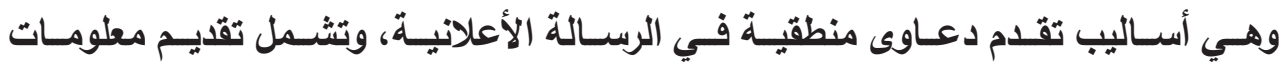

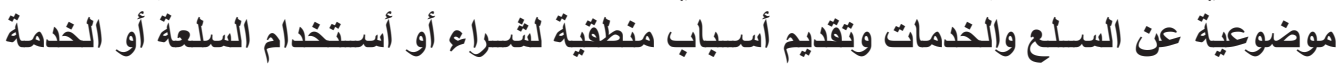

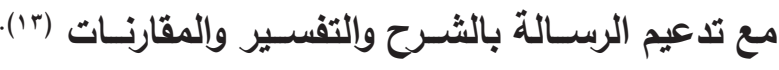
7. الاساليب اللغوية:

وهـي ادوات تسـتخدم في اللغة العربية لإضفاء جمالية خاصة ومعنـى محدد على النص (ء) (). التعريف الإجرائي للحرب الإعلانية الالكترونية: وهي مجموعة إجراءات فنية وتقتية تقوم بها الشـركات التجارية العالمية التي تنتج بضائع

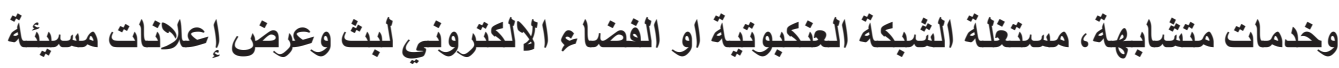

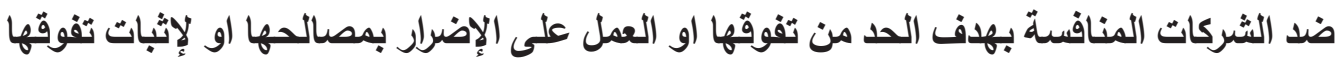
مـن خـلال افلام ونصـوص وصور تثبت رداعة المنتوج والخدمة للشـركات الاخرى المنافســة.

\begin{tabular}{l|c} 
& مجلة الباحث الاعلامي \\
\hline 17 & العدد (r )
\end{tabular}




\section{الاطار النظري : (1)}

\section{ا. تاريخ الحروب الالكترونيه الاعلانيه}

يعود تاريخ الحروب الاعلاتيه بين الشـركات التجارية الى بداية القرن التاسـع عشر، حيث قامت شركة بيبسي كولا بنشر بعض الملصقات التي تسيء بعضها للبعض الآخر وتبين تفوقها على منافتها ، وكذلك بالنسبة لشركات BMW وشركه اودي للسيارت التي أعلنت الحرب فيها فـي الثمانينـات مـن القرن الماضـي، من خلال اســخدام الفضاء الطبيعي وليـس الاكتروني،

حيـث اســخدمت الملصقـات للسـخريه مسن بعضهـم البعض فـي ولايه لـوس انجلـس .(10).

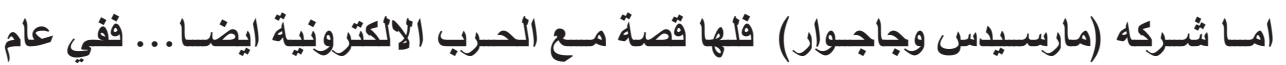

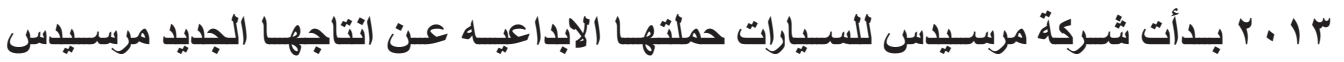

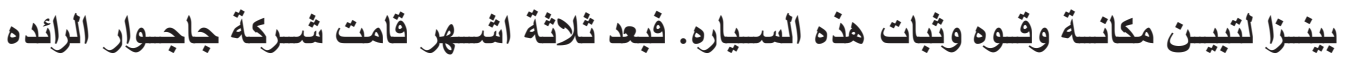
في صناعه السـيارت بتحدي شـركة مرسـيدس والمسـتخدمه نفس التقنيات التي اسـتخدمتها

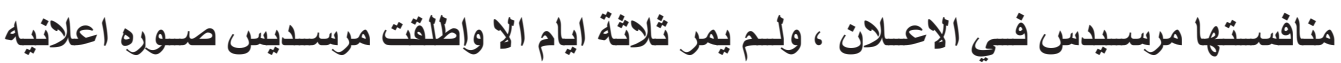
جديـده لسـياراتها ردا علـى جاجـوار التي سـرقت منها طريقـــه اعلانها .(1).

كمـا شـاركت شـركه مايكروسـوفت وجوجـل حـول جوجل كروم في الحـرب، حيث وضعت

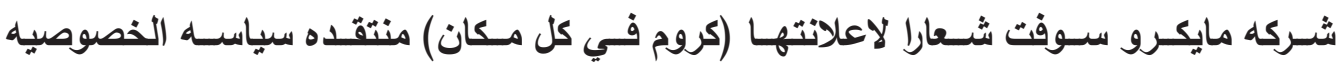

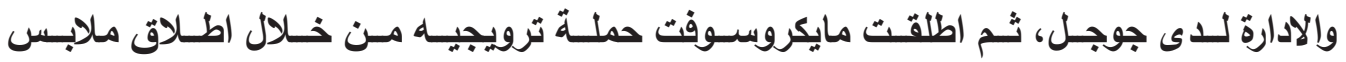

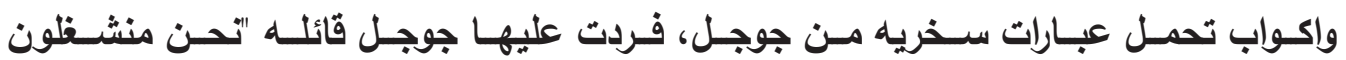

بتطويـر نظـاره جوجـل الخاصه بهـا اثناء اتشـغال مايكروسـوفت ببيع الملابـس والاكواب ".

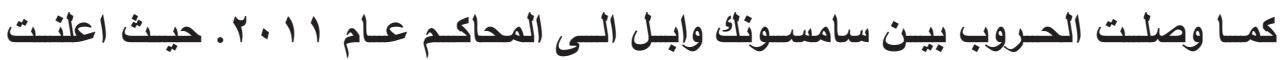
سامسـونك عـن منتوجهـا الجديــ Galaxy SY ودعـ فيــه النسـتخدمين الـى التخلـي عن Iالانتقـال الـى Iphone Galaxy (Iphone ولـــ تتنهـي الحـروب لحد لحظه كتابـهـ البحث مادام هناك انتاج جديد وشـركات تلثهث وراء

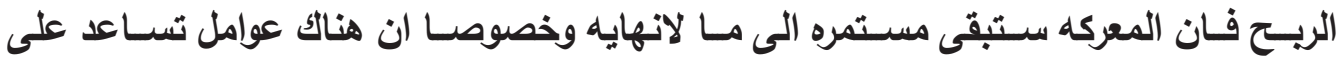
مثل هـذه الحروب الاوهـي التقتيات الجديدة المتوفرة في عالم الفضــاء الالكتروني والتي تثيح كل فرد اسـتخدامها مسـبقا حسبب ما يريد وكيفما يريد....... 


\section{r-ركائز واسس الحرب الاعلانيه التجاريه .}

اسـتخدت في الحرب التجاريه الاعلانيه الالكترونيه اسـس شـتى، منها ماهو اجتماعي ومنهــا ماهـو سياسـي وكذلك دينـي انطلقت منها بهـدف التاثير في المتلقـي وخصوصا عندما

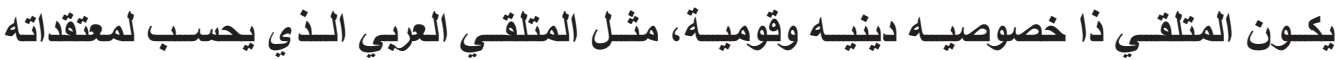

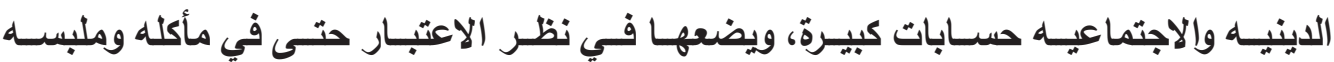

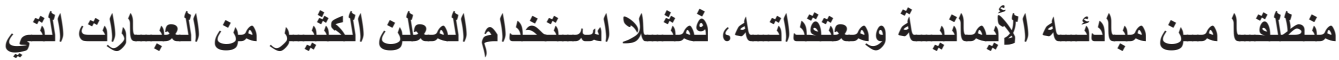

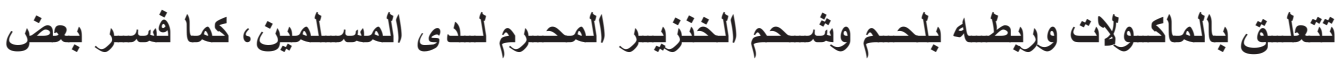
الاعلانـات وجـود كتابات مثل اسـماء الانبياء على بعض المنتجات بانهــا من المحرمات لاثاره

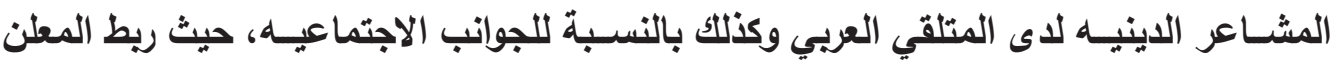

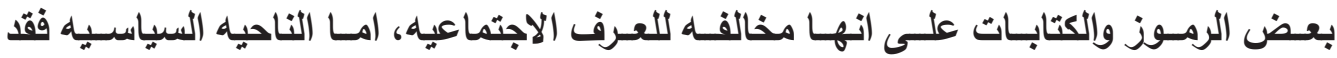
وضعـت كلمـه (اسـرائيل ) كثيرا وربطت ببعض المنتوجات على انها اسـرائيليه تشسعى لتصدير الامــراض المميتـهـ للشـعب العربـيـي .وفـي موضع اخر وضعت شـركات الاتصال بعـض الركائز

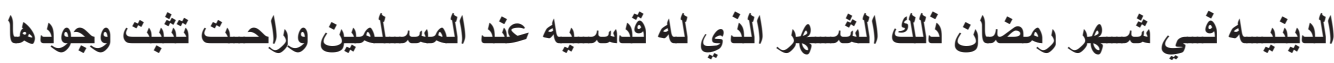

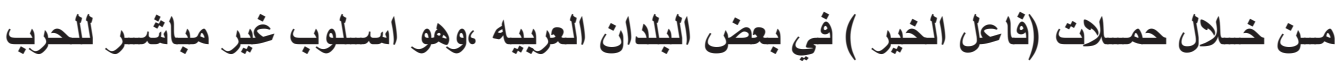

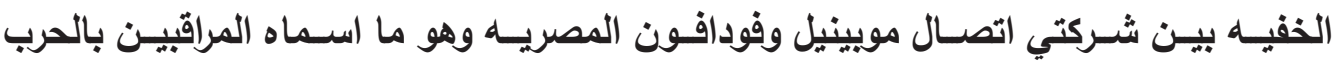

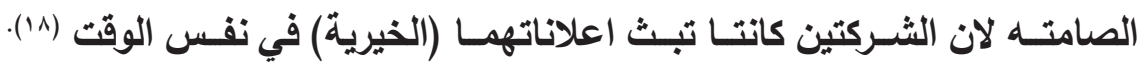

امـا للمتلةي الاجنبي فقد اسـتخدمت الركائز والمبادى ع نفسـها في هـذه الحرب الضروس بيـن شـركتي بيبسـي وكـولا (9). منــ نهايه القـرن الثامن عشـر، حيث كاتت هذه الشـركات

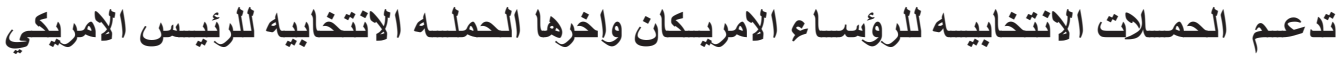

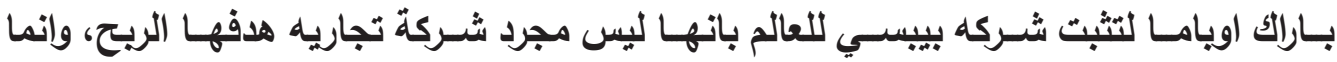
هـي جـزء مـن عمليـه التغير فـي المجتمع فيما تؤكد شـركه كـولا بانها دائما جـزيء من (الحلم الامريكي ) اذ تطرح مشـرويها (الكلاسـيكي ) الـذي يجمـع بين قيـم العائله والسـوق بصوره هادفـة ورصينـه، باعتبـاره يمثل طبقه النخبه في المجتمع الامريكي فيما تطرح شـركة بيبسـي

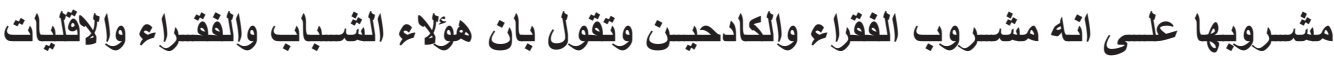

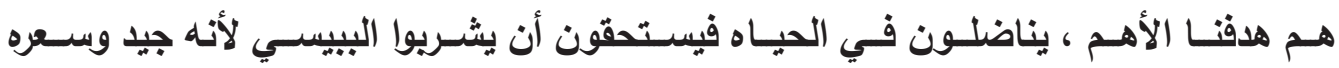

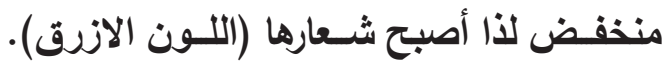

اما شـركه Xbox وشـركه playstation فقد اسـتخدمت اسـلوب متميز واثبات الوجود مـن خـلال عـرض منتجاتها علـى انها الافضـل وخصائصها وغيـر موجودة في اجهـزه اخرى.

\begin{tabular}{l|c} 
& مجلة الباحث الاعلامي| \\
\hline 11 & العدد (r (r)
\end{tabular}




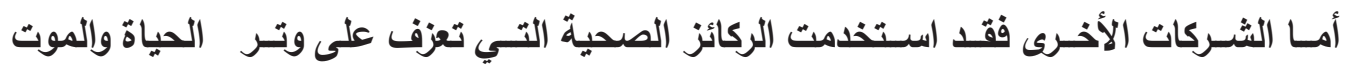
وخصوصا شـركات الماكولات والمشـرويات والادوية.

\section{r. العوامل التقنية الفنية التي ساهمت في أنجاح الحروب الأعلانية}

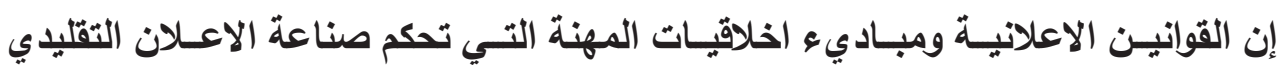

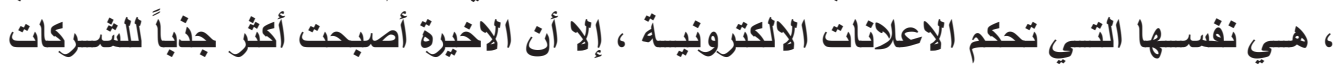

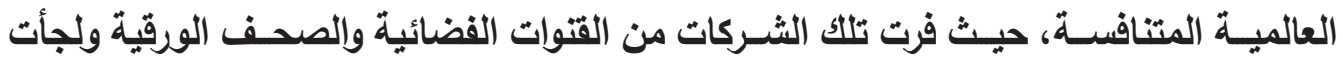

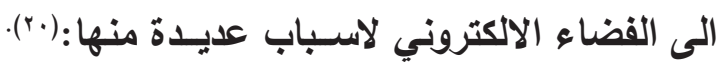

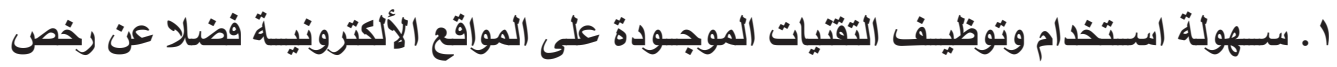

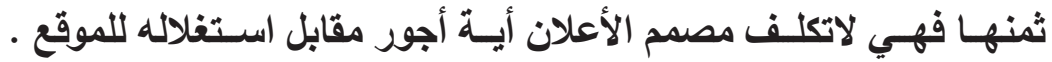

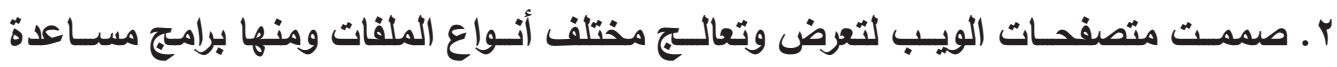

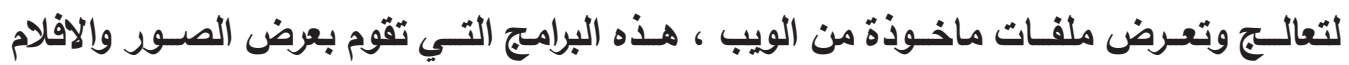

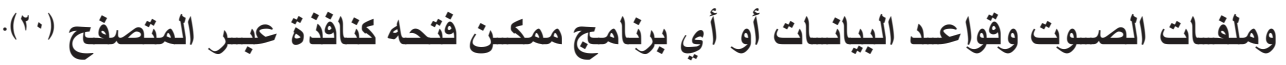

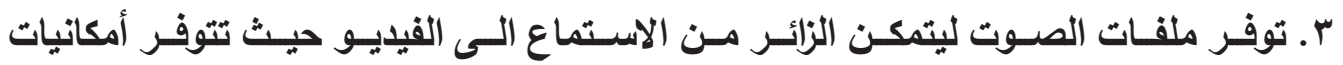

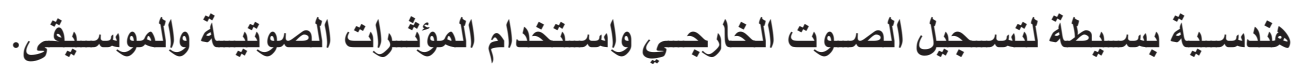

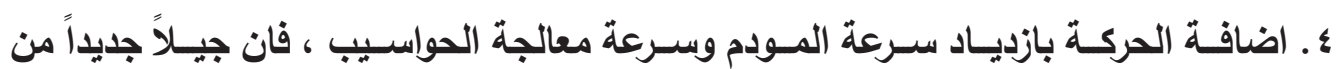

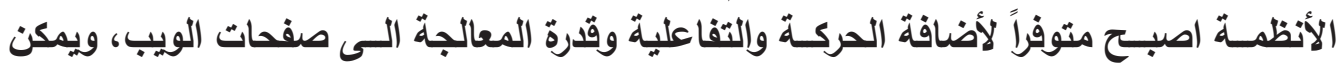

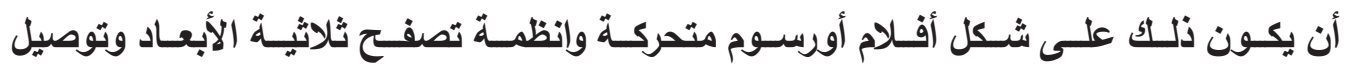
برمجيـات صغيـرة ممـا يضفي عليـهـ وظائف معالجــة جديدة.

هـ تســـح حركة المرور على الأنترنيت بثـيع من التطقل على مسائل الخصوصية الثخصية

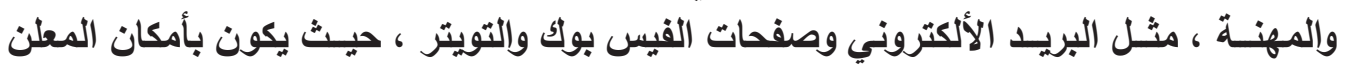
أسـتخدام هذه الصفحات والاخول بأعلاناتها (عنوة ) الى المتابعين.

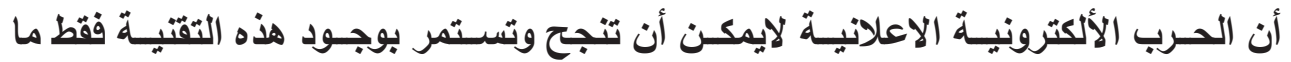

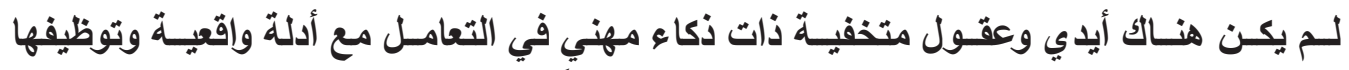

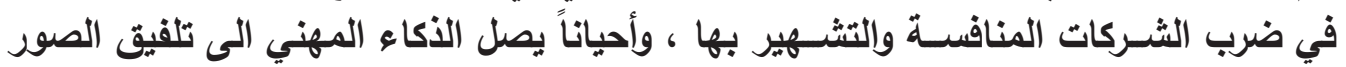

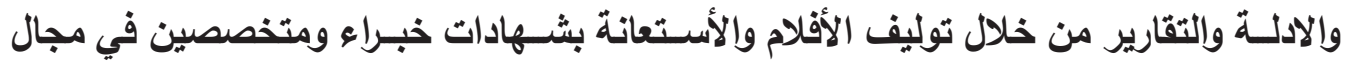


عــوم الطـب والأمسراض لاثبـات صحة أدعاءاتهم، ورغـم كل ذلكت يبقى المسـتهلك هو الضحية

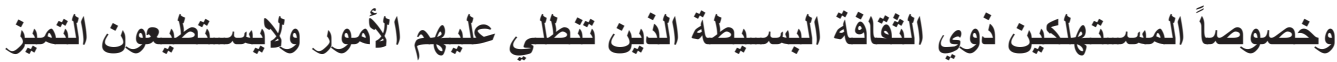

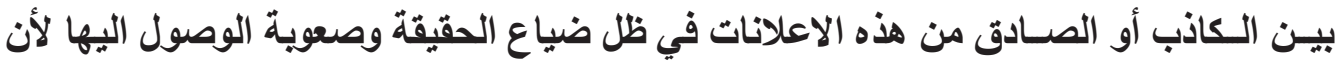

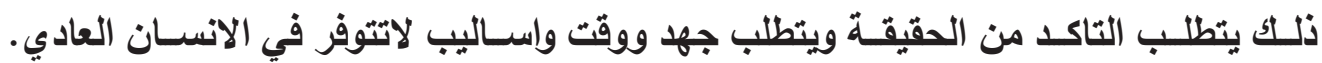

الاطار الميداني أولاً: نتائج التحليل : ا. أنواع الشركات المستهدفة في الحرب الأعلانية.

تبين للباحثة بأن العينة البالغة (1 آ) اعلاناً قـ توزعت على الثركات العالمية كالآتي: حيث بلفت نسـبة المواد الغذائية والمشـرويات أعلى نسـبة من أنواع الثركات التي شملتها

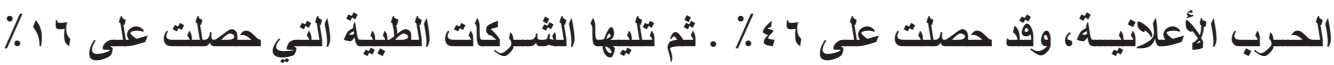

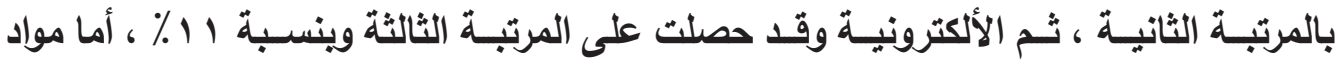

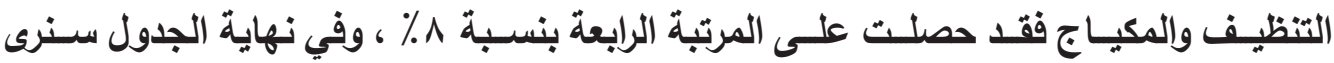

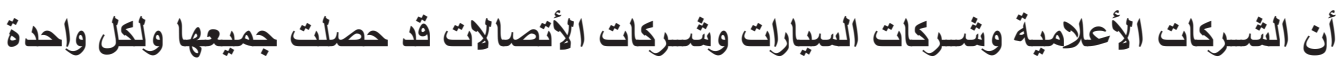

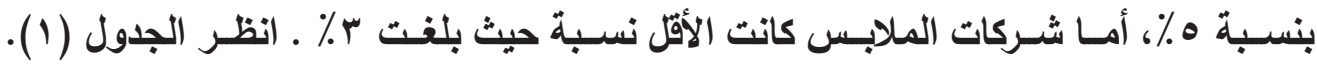
جدول (1) يبين أذواع الشـركات

\begin{tabular}{|c|c|c|c|}
\hline المرتبة & $\%$ & $ت$ & الثركات \\
\hline الاولى & $\% \leqslant 4$ & $r \wedge$ & الغذائية والمشروبات \\
\hline الثاتية & $\% 17$ & 1. & الطبية \\
\hline الثالثة & $\% 11$ & 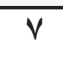 & الأكترونية \\
\hline الرابعة & $\% \wedge$ & 0 & مواد التنظيف والمكياج \\
\hline الخامسة & $\%$ & $r$ & الأعلامية \\
\hline الخامسة & $\%$ & $r$ & السيارات \\
\hline الخامسة & $\%$ & $r$ & الاتصالات الهاتفية \\
\hline السـادسة & $\% r$ & $r$ & الملابس \\
\hline & $\% 1 \ldots$ & 91 & المجموع \\
\hline
\end{tabular}

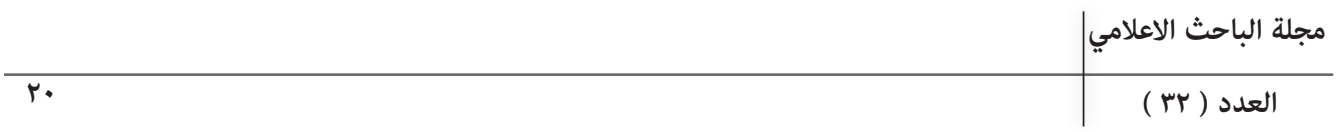




\section{ץ • أنواع الاعلانات المستخدمة في الحرب الألكترونية}

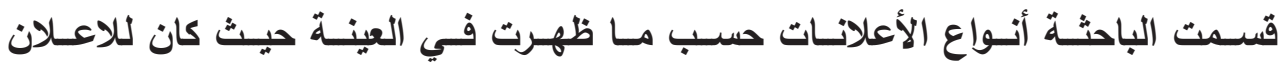

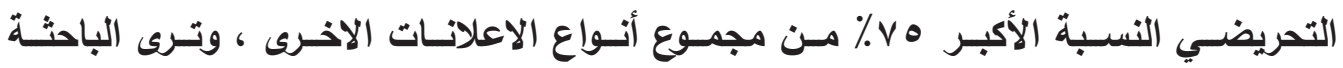

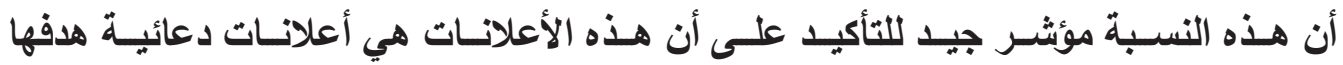

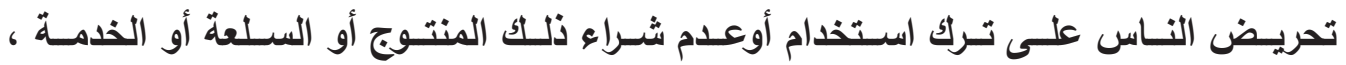

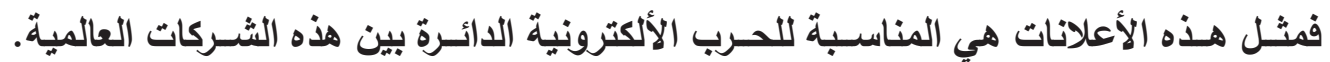

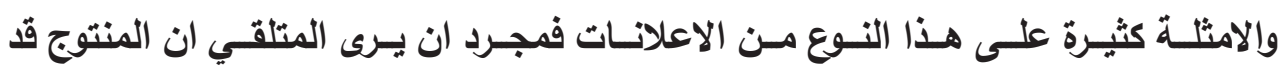

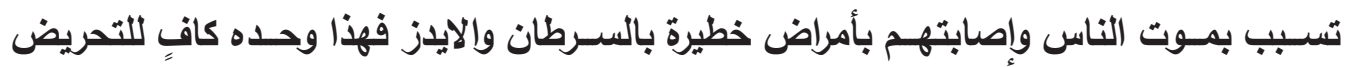

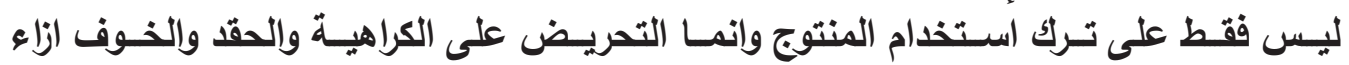

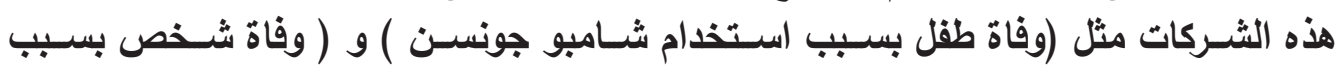

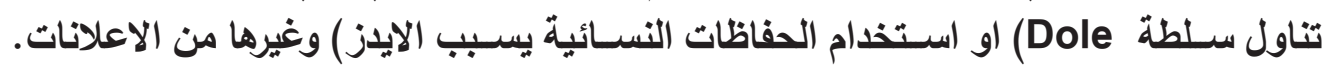
أما المرتبة الثانية فقد حصل عليها النوعان المقارن والتوجيهي وينسبة ^٪ لكل منهما .

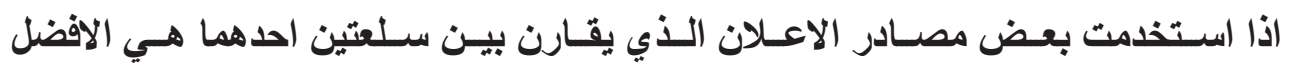

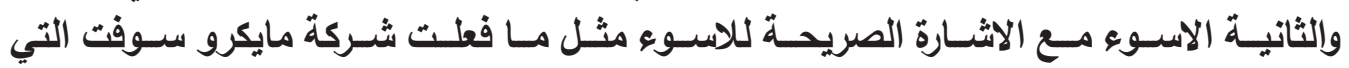

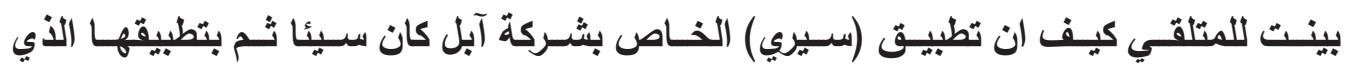

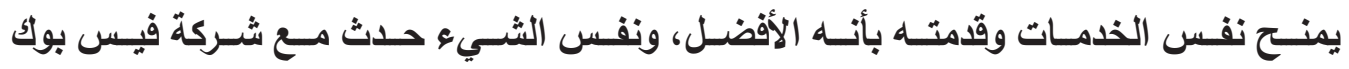

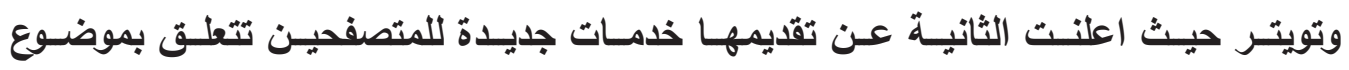

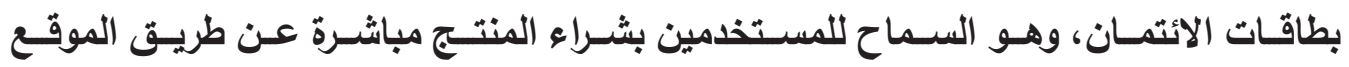

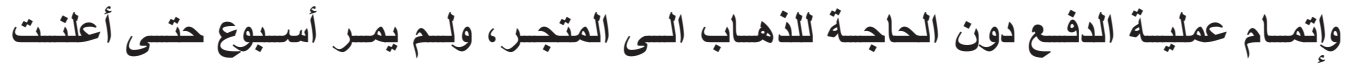

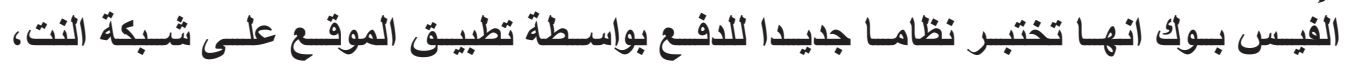

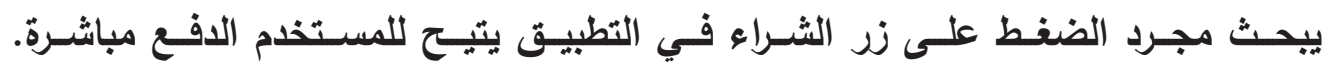
اما الاعلان التوجيهي والذي حصل على نفس النسبة ^٪ ـ . فهو من الاعلانات التي تحاول

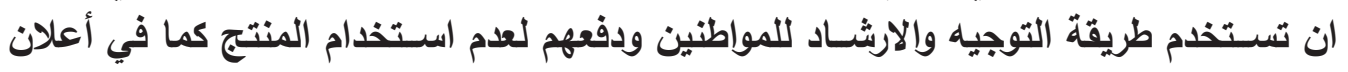

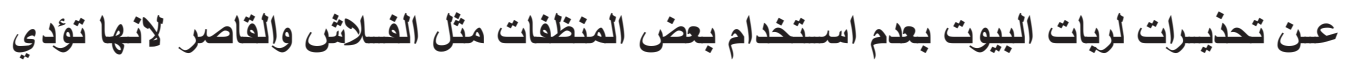
الى اضرار صحية ثم الوفاة أو عدم الافراط في تتاول الثـاي الأخضر الأي يسـبب السـرطان.

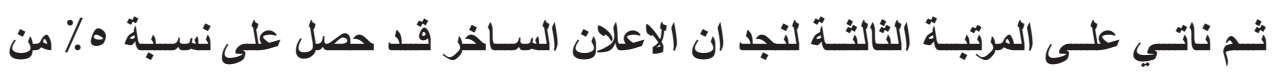

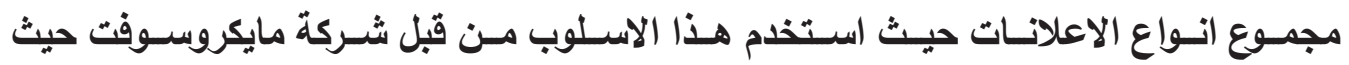

مجلة الباحث الاعلامي| 
اظهـرت اعـلان فيلمي يبيـن احد الممثلين كيف يُحرج عندما اســتخدم تطبيـق على انه محمي

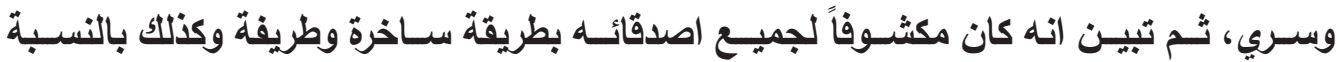

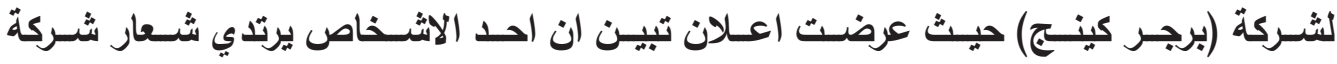

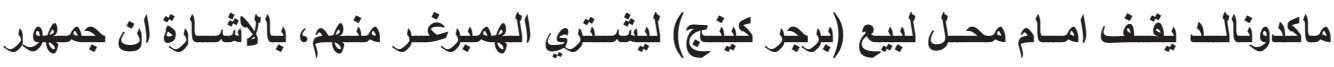

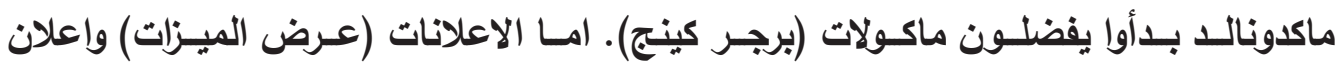

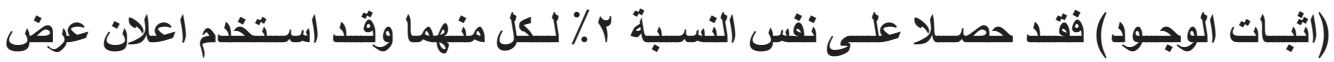

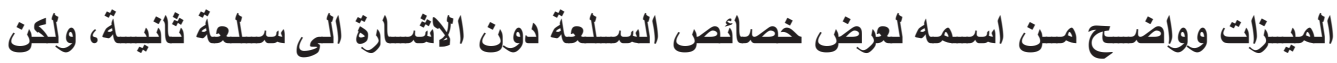

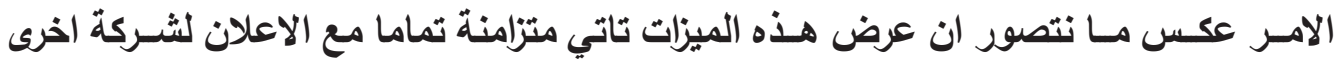

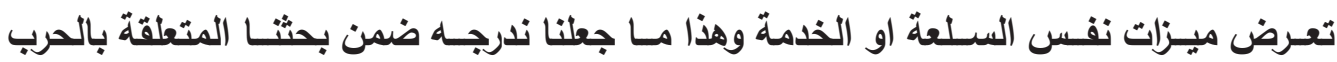

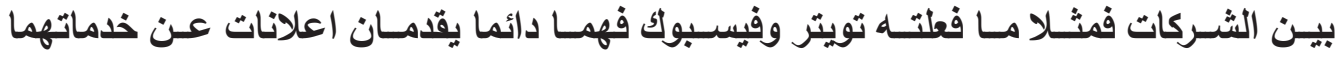

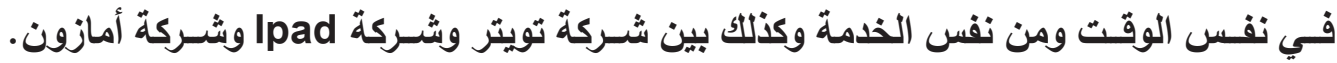

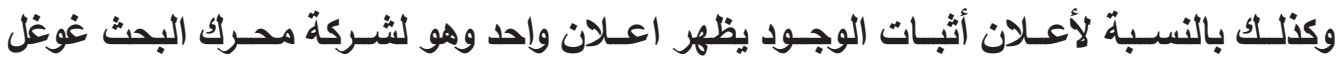

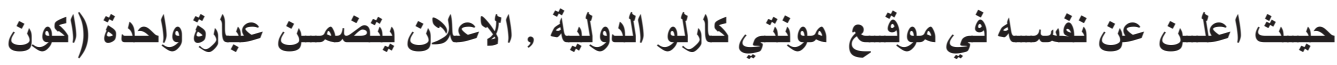

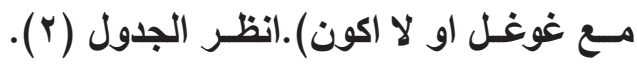

\section{جدول (ץ) يبين انواع الاعلانات المسدتخدمة في الحرب الألكتروذية}

\begin{tabular}{|c|c|c|c|}
\hline المرتبة & $\%$ & ت & انواع الاعلانات \\
\hline الاولى & $\% \vee 0$ & $\leq 7$ & تحريضي \\
\hline الثانية & $\% \wedge$ & 0 & مقارن \\
\hline الثانية & $\% \wedge$ & $\bullet$ & توجيهي \\
\hline الثالثة & $\%$ & $r$ & ساخر \\
\hline الرابعة & $\% r$ & 1 & عرض الميزات \\
\hline الرابعة & $\% r$ & 1 & اثبات الوجود \\
\hline & $\% 1 \ldots$ & 71 & المجموع \\
\hline
\end{tabular}

r. أشكال الاعلانات

صُنفت الباحثة اشكال الاعلانات في العينة بناءا على طريقة تصويرها وعرضها فكانت كالاتي:

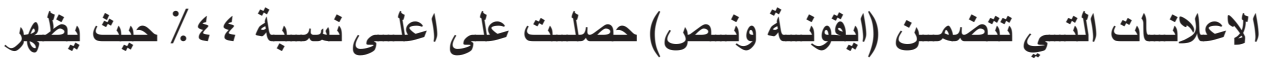

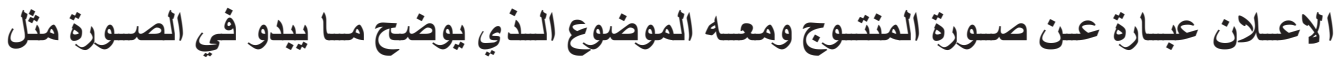

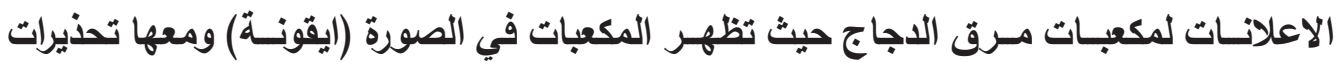




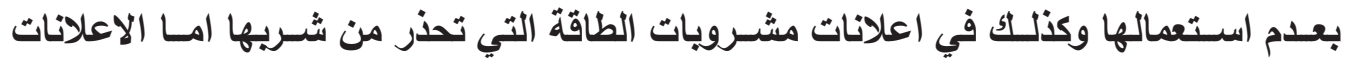

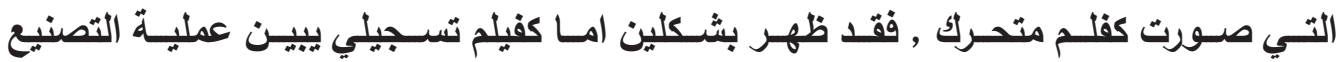

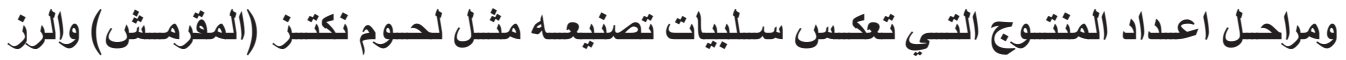

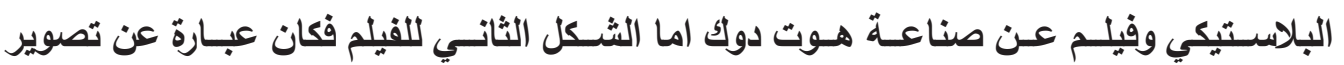

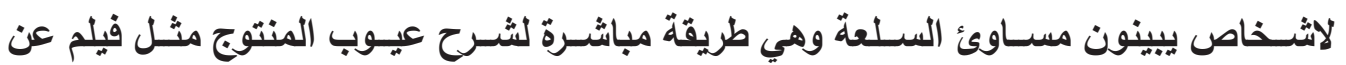

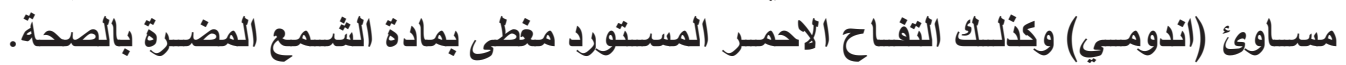

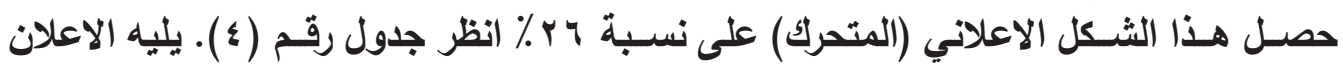

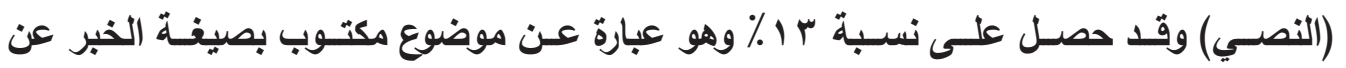

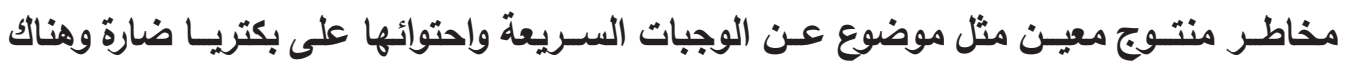

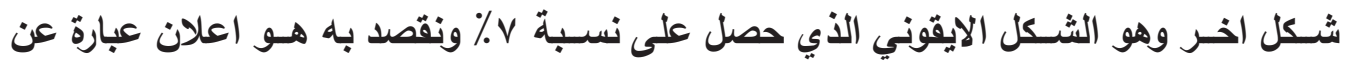

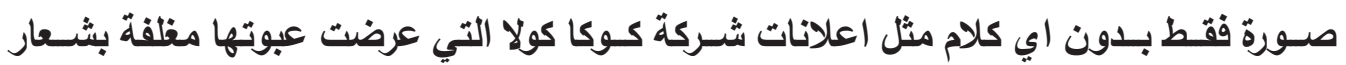

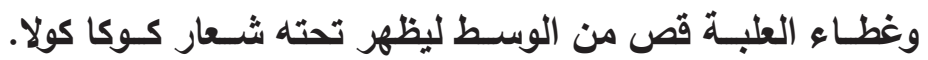

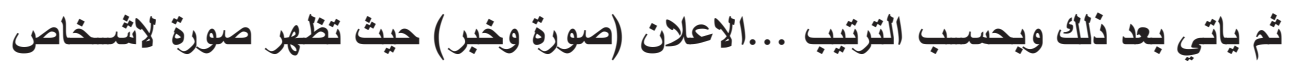

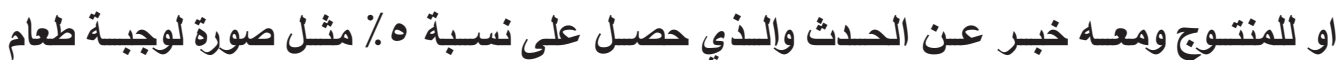
(سـتاريكس) وفي وسـطها حشـــة ومـع الصورة خبر عـن الموضوع.

امـا الثـكل الاعلانـي الاخر هو القصـة الخبرية حيث كتب الموضوع بثـكل قصة خبرية

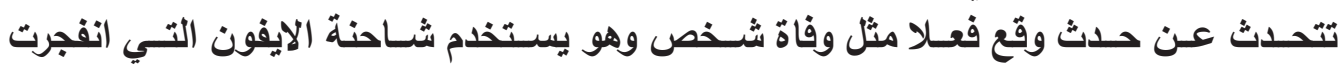

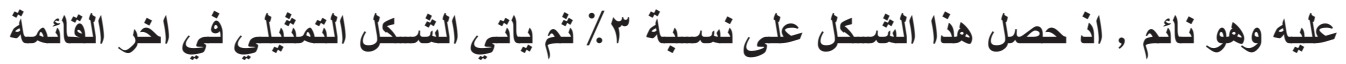

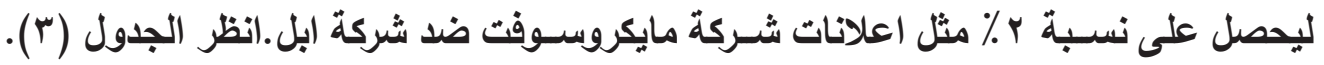
جدول (r) يبين اشـكال الاعلانات (طريقة عرض الاعلان)

\begin{tabular}{|c|c|c|c|c|}
\hline المرتبة & $\%$ & 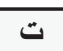 & اشكال الاعلانات & 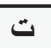 \\
\hline & $\% \varepsilon \varepsilon$ & rV & ايقوني/نصي & 1 \\
\hline & $\% 44$ & 17 & متحرك (فيلم) & $r$ \\
\hline & $\%$ & $\Lambda$ & نصي (خبر) & $r$ \\
\hline & $\% \vee$ & $\varepsilon$ & ايقوني & $\varepsilon$ \\
\hline & $\% 0$ & $r$ & صورة وخبر & 0 \\
\hline & $\% r$ & r & قصة خبرية & 7 \\
\hline & $\% r$ & 1 & تمثيلي & $\mathrm{V}$ \\
\hline & $\% 1 \ldots$ & 71 & المجموع & \\
\hline
\end{tabular}

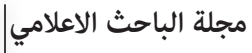


جدول (؛) يبين اشـكال الاعلان الفيلمي

\begin{tabular}{|c|c|c|}
\hline$\%$ & ت & اشكال الاعلانات \\
\hline$\% 17$ & 1. & تسجيلي \\
\hline$\% 1$. & 7 & مباشر \\
\hline$\%$ rq & 17 & المجموع \\
\hline
\end{tabular}

ع .الاساليب الاقناعية العاطفية:

ظهـرت فـي نتائـج التحليـل ان الاسـاليب الاقتاعيـة العاطقية التي اسـتخدمت فـي الحرب الالكترونيـة كانــت كالاتي: فئسئ

أول أسـلوب هـو اسـلوب (الترهيب) وقد حصـل على 9 ؛ ٪ وعادة ما يتم الترهيب بواسـطة

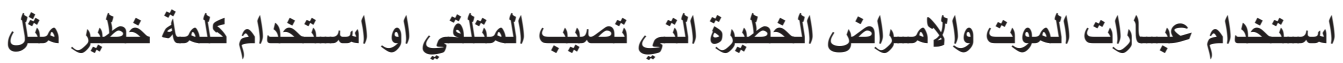

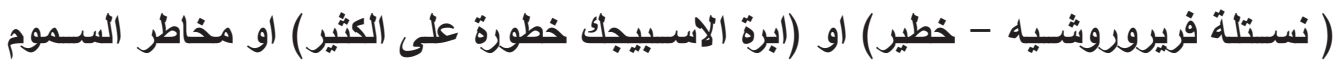

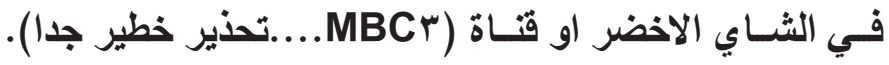

اما الاسلوب الثاني فكان اسلوب الصدمة وقد حصل على 1 ٪ وهو اسلوب يفاجيء المتلقي

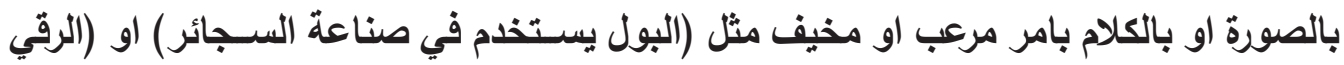

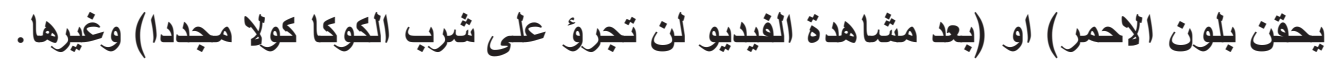

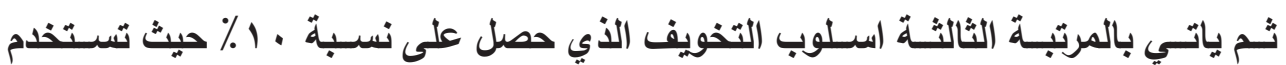

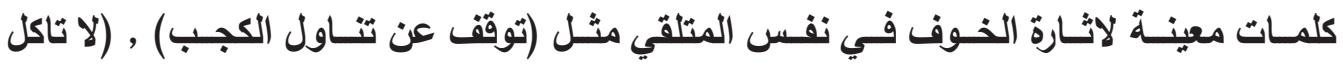

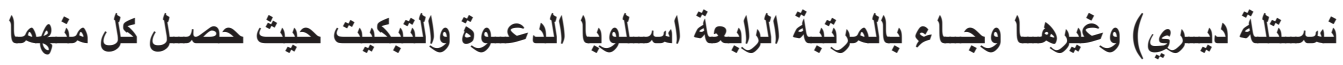

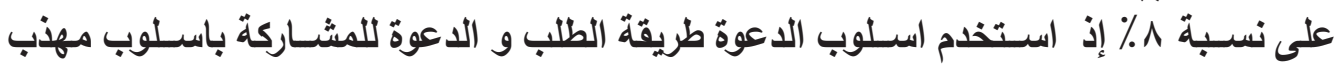

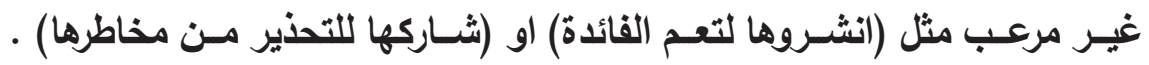

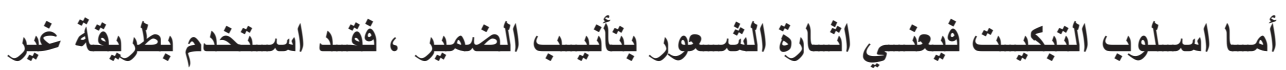

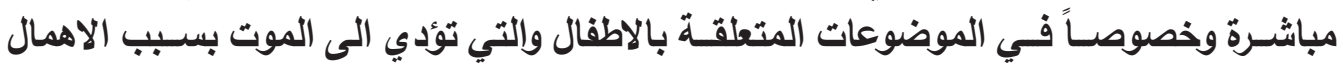
والتقصير مـن الكبار. 


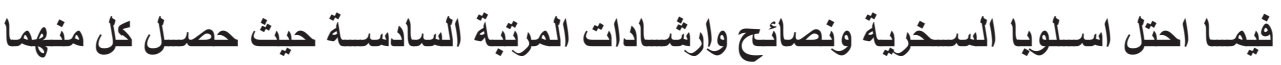

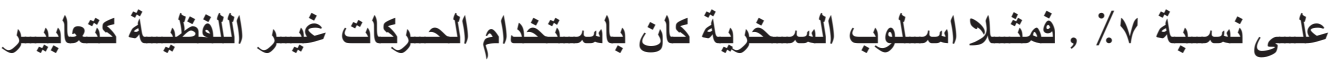

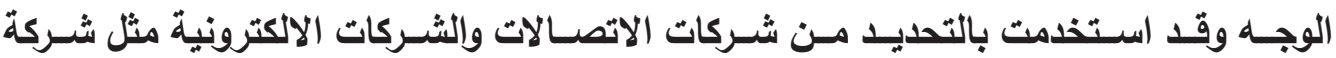
مايكروسـوفت وشـركة الاتصـالات الهاتفية.

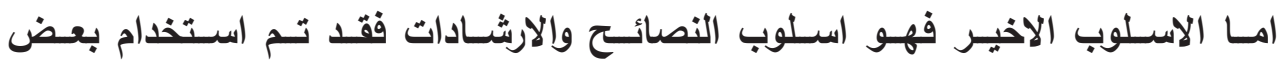

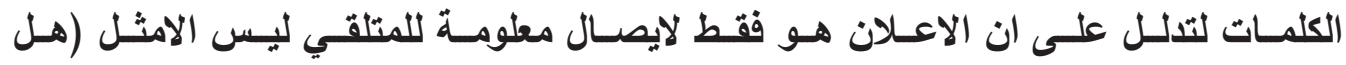

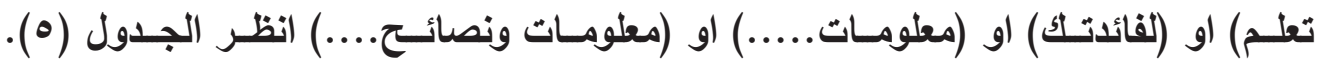
جدول (•) يبين الاسداليب الاقناعية العاطفية

\begin{tabular}{|c|c|c|c|c|}
\hline المرتبة & $\%$ & ت & الاسـاليب العاطفية & ت \\
\hline الاولى & $\% \leqslant q$ & $r$. & التر هيب & $r$ \\
\hline الثانية & $\% 11$ & $v$ & الصدمة & $r$ \\
\hline الثالثة & $\% 1$ & 7 & التخويف & $\varepsilon$ \\
\hline الرابعة & $\% \wedge$ & 0 & الدعوة والطلب & ○ \\
\hline الرابعة & $\% \wedge$ & 。 & التبكيت & 9 \\
\hline الخامسة & $\% \vee$ & $\varepsilon$ & نصائح وارشادات & $v$ \\
\hline \multirow[t]{2}{*}{ الخامسة } & $\% v$ & $\varepsilon$ & السخرية & $\wedge$ \\
\hline & $\% 1 \ldots$ & 91 & المجموع & \\
\hline
\end{tabular}

\section{ه.الاساليب الاقناعية العلمية}

حـاز اسـلوب الحجـج والادلة والبراهيـن على اعلى نسـبة بين الاسـاليب الاقتاعية العلمية

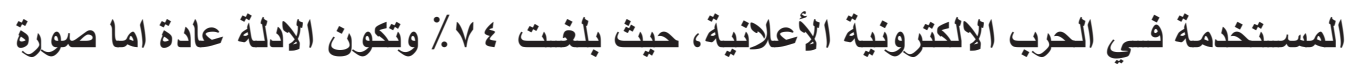

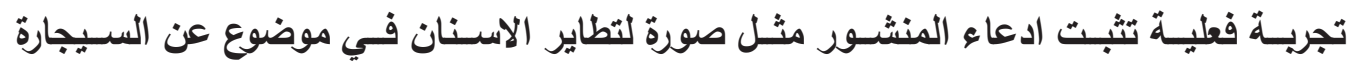

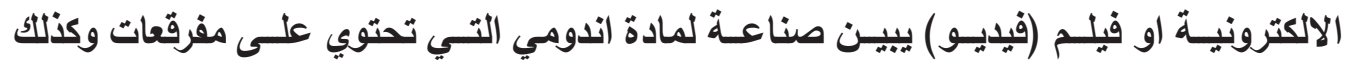

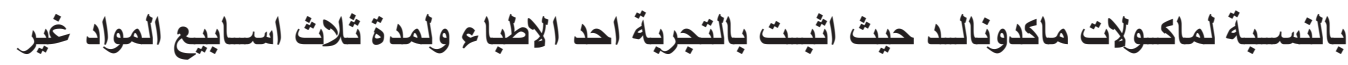
الصحيـة التي تلدخل في صناعة (بركـر ماكدونالا) . 


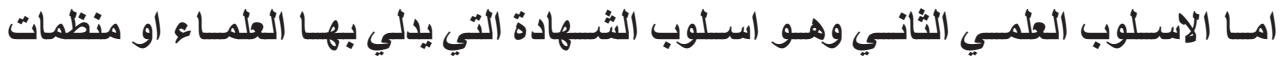

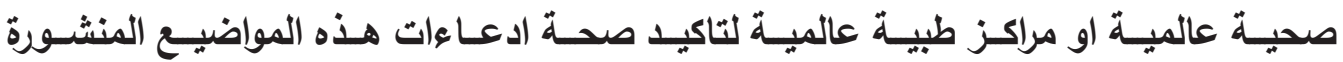

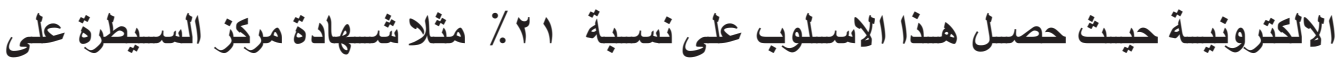

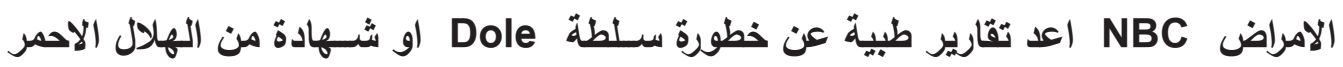

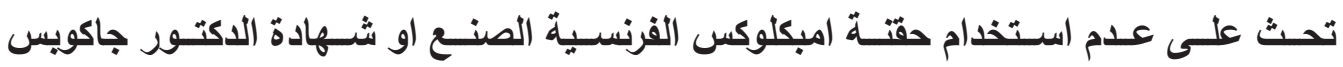

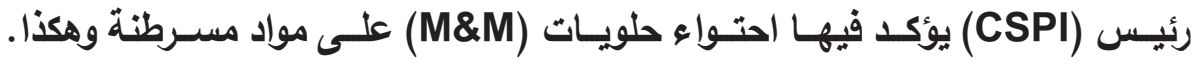

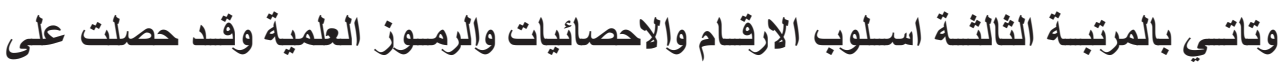

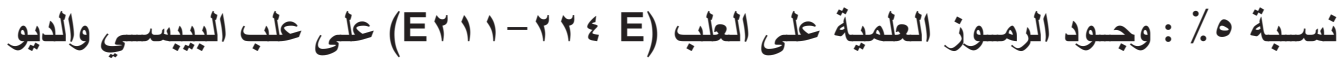

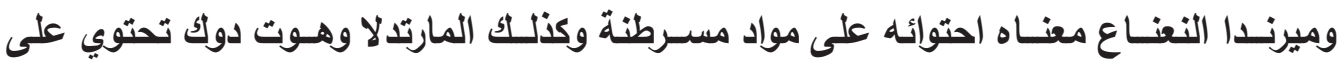

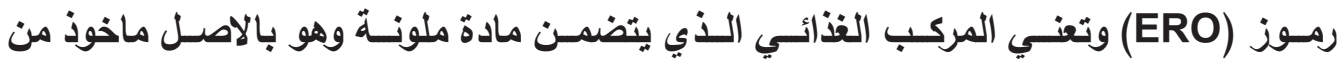

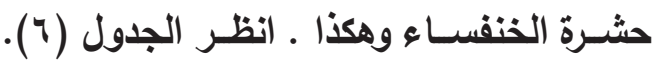
جدول(†) يبين الاسـاليب الاقناعية العدلمية

\begin{tabular}{|c|c|c|c|}
\hline المرتبة & $\%$ & $ت$ & الاساليب العاطفية \\
\hline الاولى & $\% \vee \leq$ & $\leqslant 0$ & الحجج والادلة والبراهين \\
\hline الثانية & $\% Y_{1}$ & ir & شهادة العلماء \\
\hline \multirow[t]{2}{*}{ الثالثة } & $\%$ & r & الارقام والرموز \\
\hline & $\% 1 \ldots$ & 71 & المجموع \\
\hline
\end{tabular}

\section{7.الاساليب اللغوية}

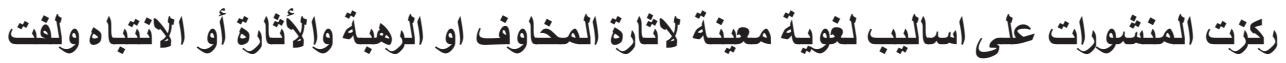

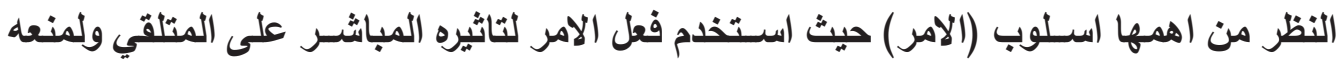

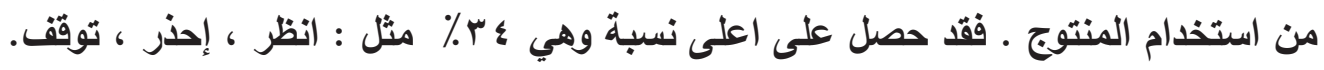

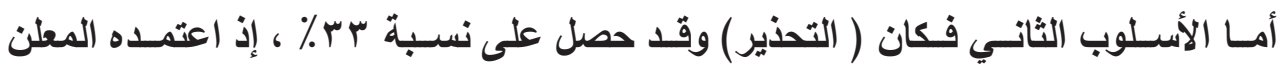

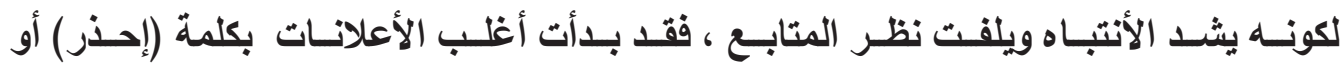

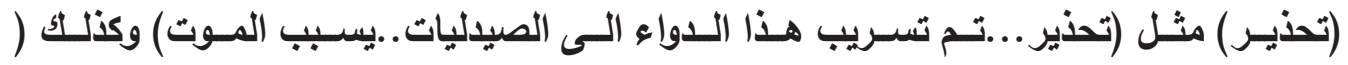

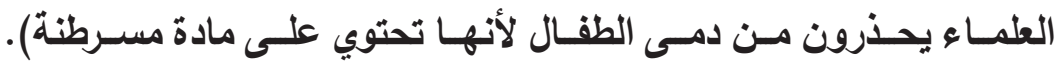




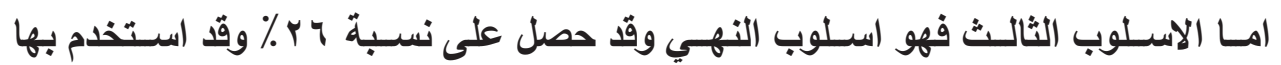

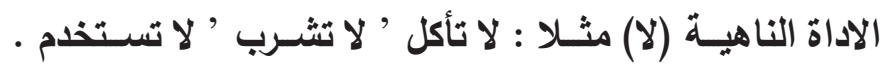

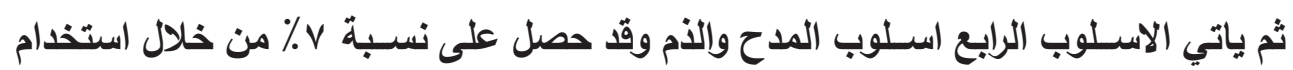

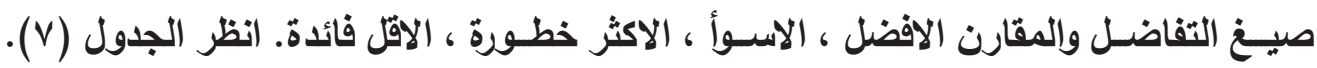
جدول (V) يبين الاسداليب اللغوية

\begin{tabular}{|c|c|c|c|}
\hline المرتبة & $\%$ & ت & الاساليب اللغوية \\
\hline الاولى & $\%$ & YI & الامر \\
\hline الثانية & \% & $r$. & التحذير \\
\hline الثالثة & $\%$ \% & 17 & النهي \\
\hline \multirow[t]{2}{*}{ الر ابعة } & $\% v$ & $\varepsilon$ & المدح والذم \\
\hline & $\% 1 \ldots$ & 71 & المجموع \\
\hline
\end{tabular}

\section{V . الاساليب الفنية المسموعة . V}

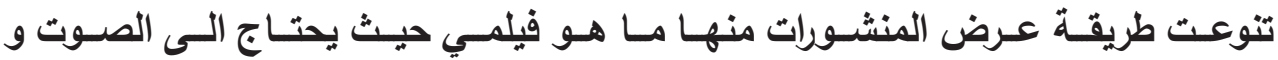

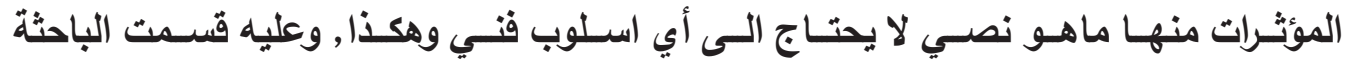

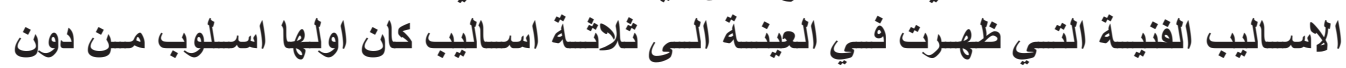

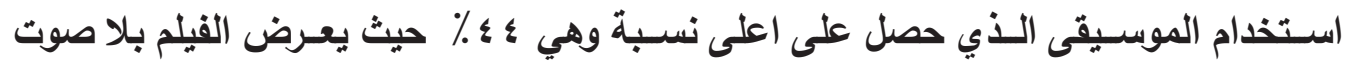

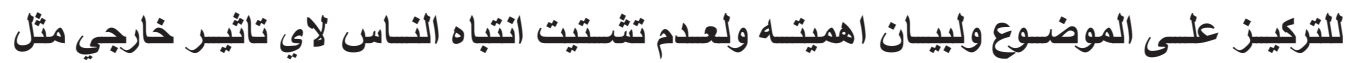

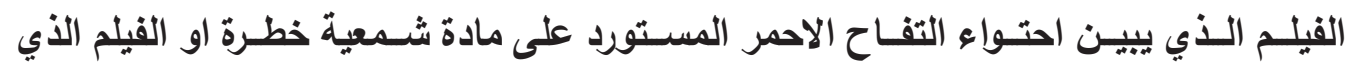

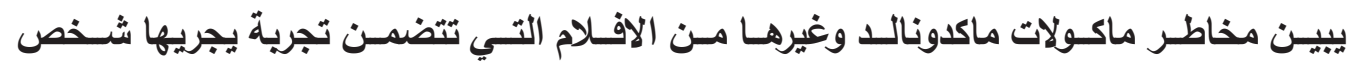

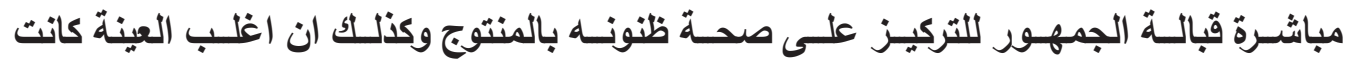

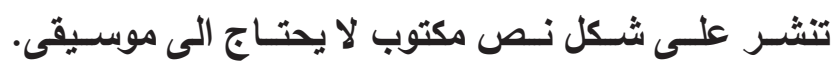

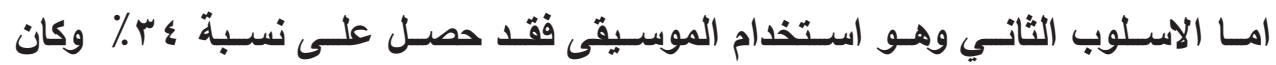

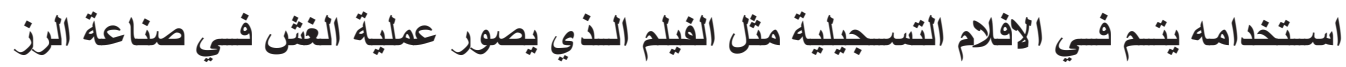
البسـمتي او صناعـة الهـوت دوتك او صناعـة الخـس الصيني. 


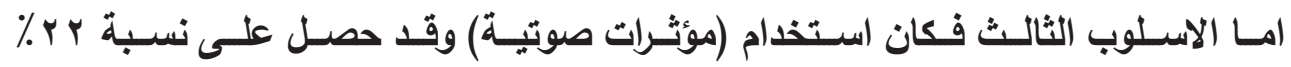

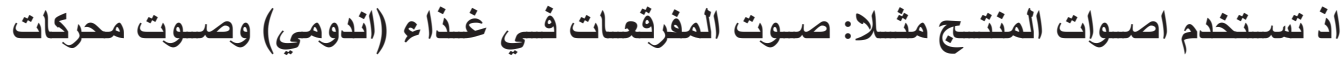
السـيارات في اعلانـات سـيارات مرسـيدس وفـورد وجاجـوار و BMW. انظـر الجـدول (^).

جدول (^) يبين الاسـاليب الفنية المسدمومة

\begin{tabular}{|c|c|c|c|}
\hline المرتبة & $\%$ & ت & الاساليب القنية \\
\hline الاولى & $\% \leq \varepsilon$ & rv & بدون موسيقى \\
\hline الثانية & $\%$ & YI & موسيقى \\
\hline \multirow[t]{2}{*}{ الثالثة } & $\% r r$ & ir & مؤثرات صوتية \\
\hline & $\% 1 \ldots$ & 71 & المجموع \\
\hline
\end{tabular}

^.الاسس التي اعتمدها المعلن في حربه :

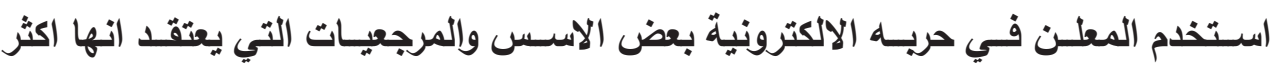

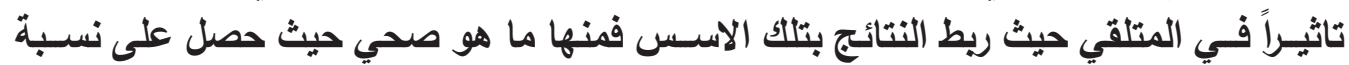

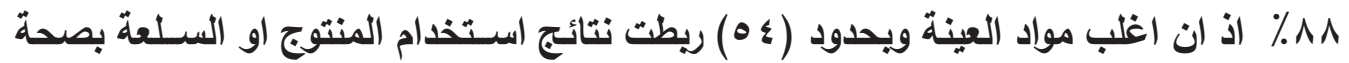

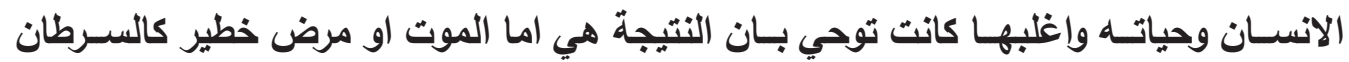

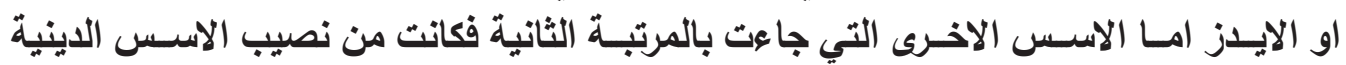

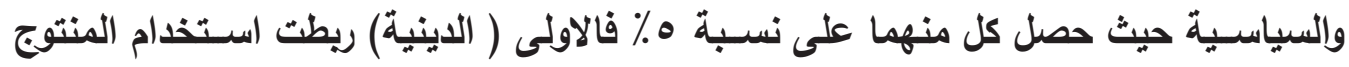

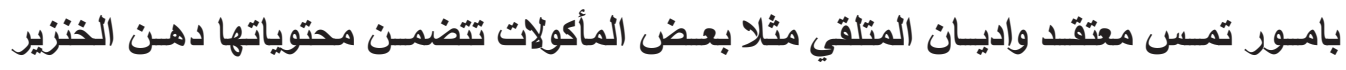

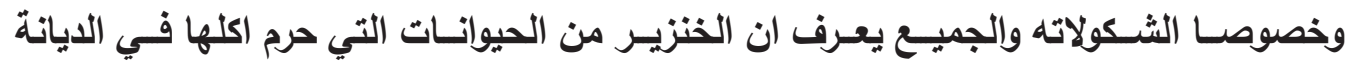

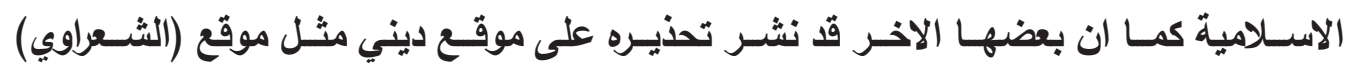

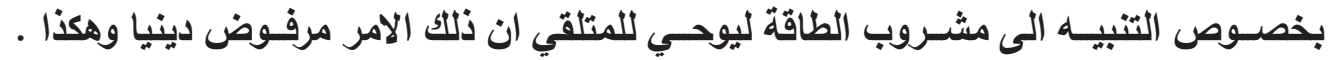
اما الجاتب السياسي فقد ريطت استخدامات بعض السلع والمنتوجات بانها قادمة او مصنعة

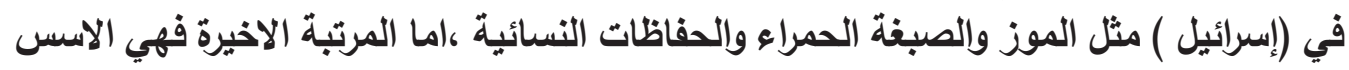

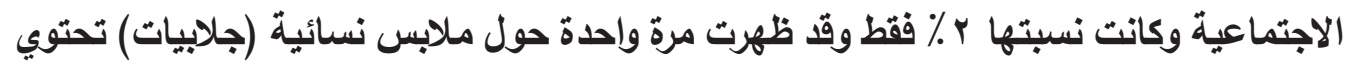

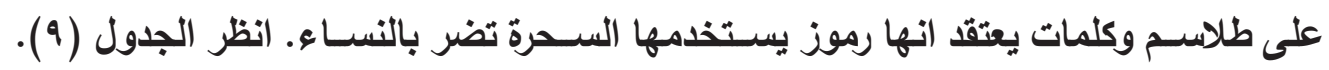


جدول (9) يبين الاسدس المعتمدة في الحرب الاعلانية

\begin{tabular}{|c|c|c|c|}
\hline المرتبة & $\%$ & $ت$ & الاسس \\
\hline الاولى & $\% \wedge \wedge$ & $0 \leq$ & الصحية \\
\hline الثانية & $\%$ & $r$ & دينية \\
\hline الثانية & $\%$ & $r$ & سياسية \\
\hline \multirow[t]{2}{*}{ الثالثة } & $\% r$ & 1 & الاجتماعية \\
\hline & $\% 1 \ldots$ & 71 & المجموع \\
\hline
\end{tabular}

9. المواقع التي نشرت الاعلانات حسب لغتها

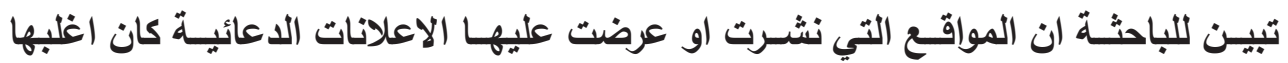

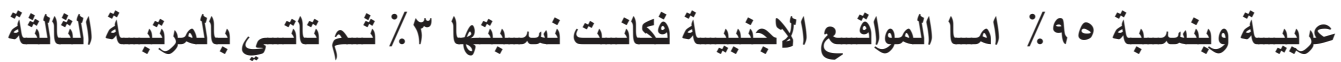

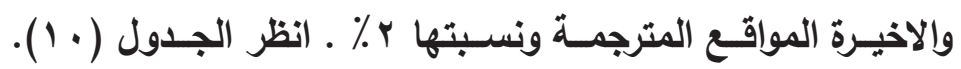

جدول ( •1) يبين اهم المواقع التي نشـرت الاعلانات حسدب لغتها

\begin{tabular}{|c|c|c|c|}
\hline المرتبة & $\%$ & $ت$ & المواقع حسب اللغة \\
\hline الاولى & $\% 90$ & $0 \wedge$ & العربية \\
\hline الثانية & $\% r$ & r & الاجنبية \\
\hline \multirow[t]{2}{*}{ الثالثة } & $\% r$ & 1 & المترجمة \\
\hline & $\% 1 \ldots$ & 11 & المجموع \\
\hline
\end{tabular}

•ا ـ اهم الروابط التي عرضت فيها الاعلانات على صفحة الفيس بوك

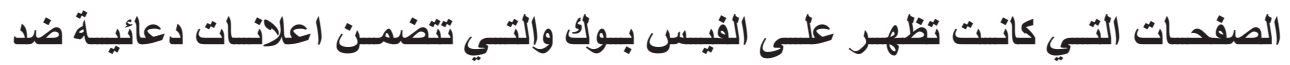

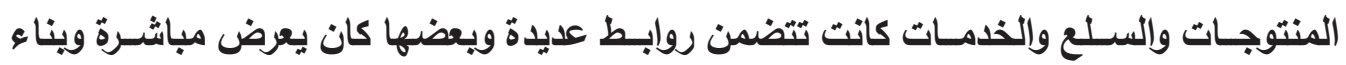

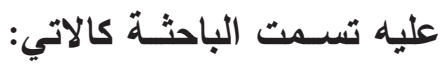

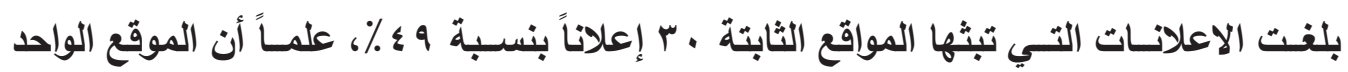


كان يبث أكثر من إعلان.

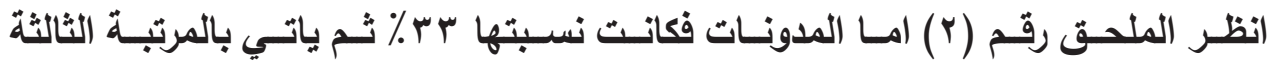

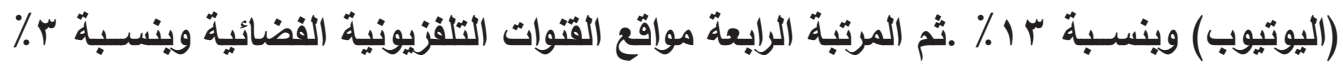

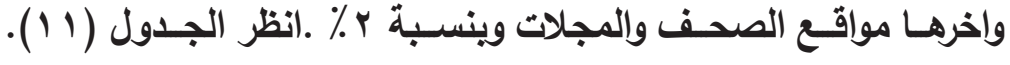

جدول (11) يبين الهم الروابط الدسدتخدمة في الحرب الدعائية

\begin{tabular}{|c|c|c|c|}
\hline المرتبة & $\%$ & $ت$ & مواقع \\
\hline الاولى & $\% \leq q$ & r. & مواقع ثابتة \\
\hline الثانية & rr\% & $r$. & مدونـات \\
\hline الثالثة & $\%$ & $\wedge$ & يوتيوب \\
\hline 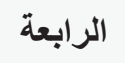 & $\% r$ & r & مواقع القتوات الفضائية \\
\hline \multirow[t]{2}{*}{ الخامسة } & $\% r$ & 1 & مواقع الصحف والمجلات \\
\hline & $\% 1 \ldots$ & 71 & المجموع \\
\hline
\end{tabular}

الخاتمة

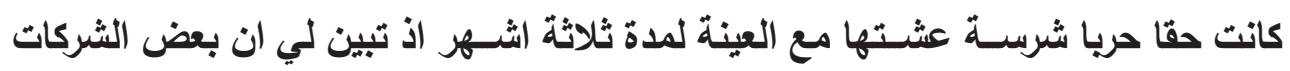

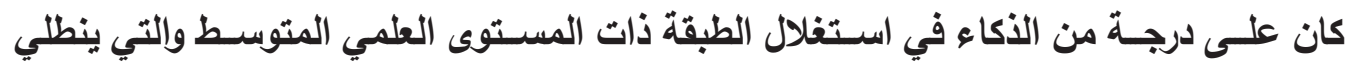

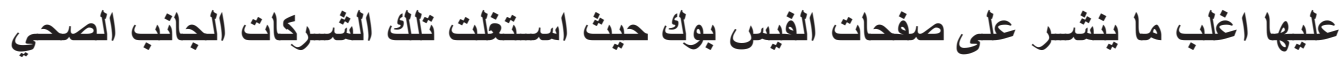

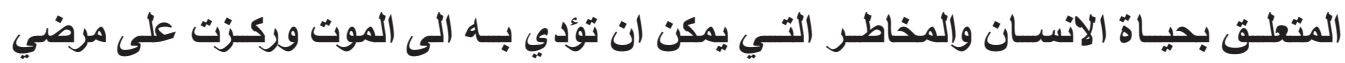

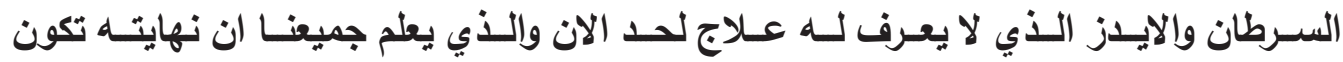

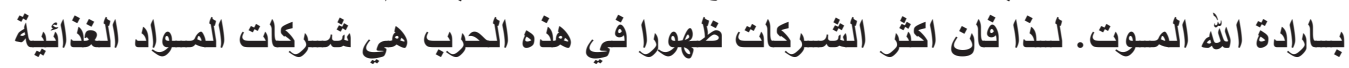

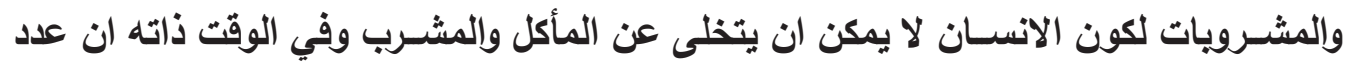

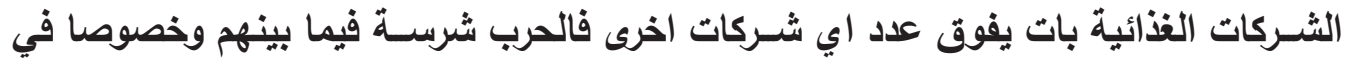

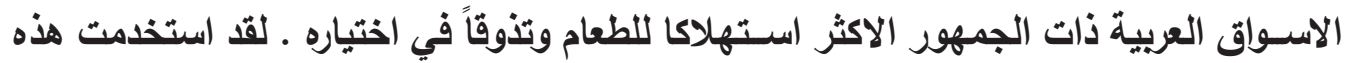

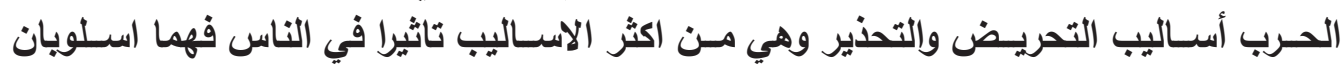

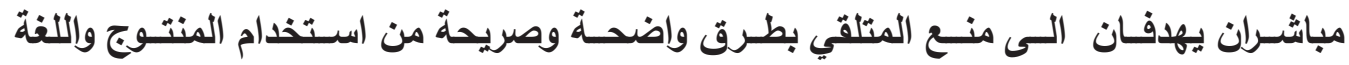
العربية مليئة بالاسـاليب المؤثرة والموجهة بصورة مباشـرة مثل اسلوب الامر والتهي وغيرهما. 


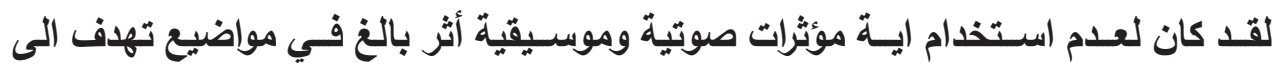

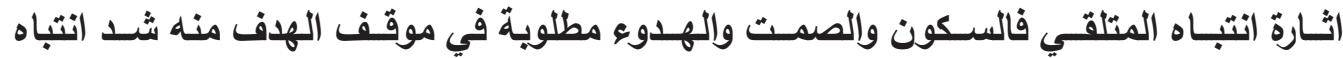

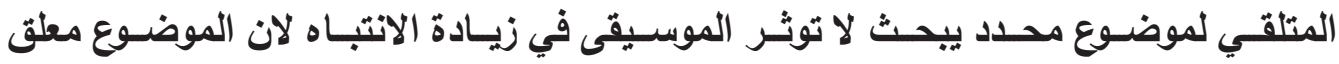

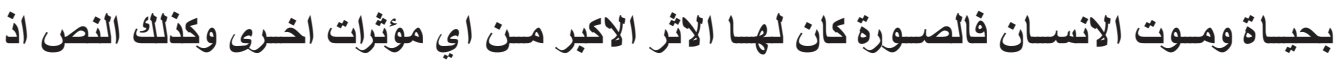

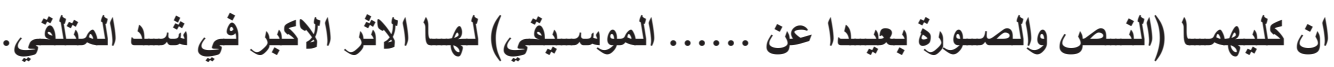
ولزيــادة الاقتــاع والتاثيـر فـان المصدر لم يتورع في اسـتخدام صور صادقـة تثير الغثيان

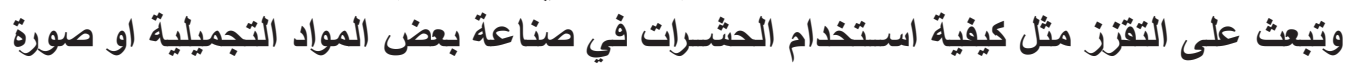

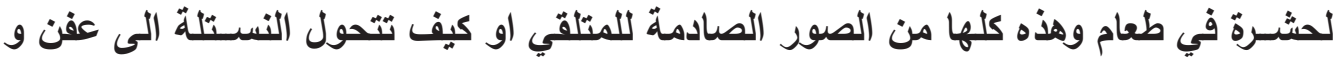

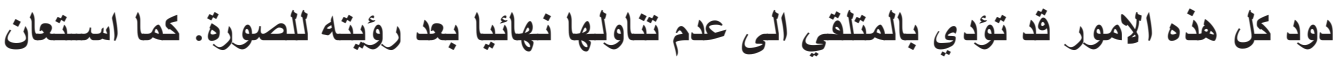

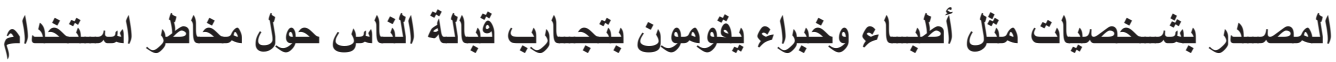

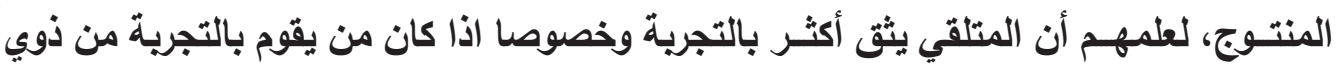

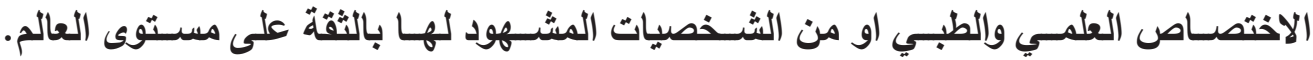

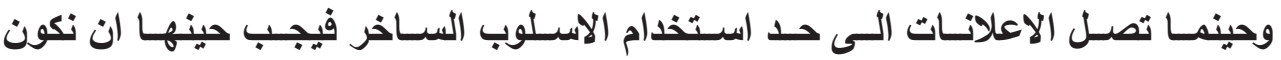

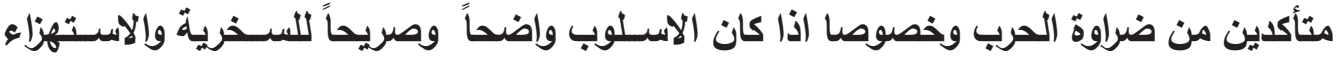

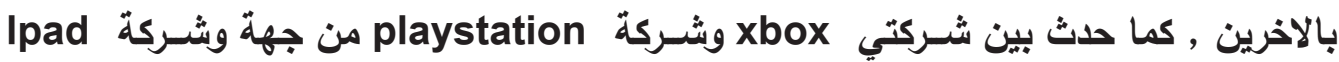

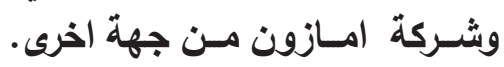

لقـــ اسـتفلت الشــركات العربية و الاجنبية معتقدات الشـعوب واديانهـا للتاثير في قتاعاتها

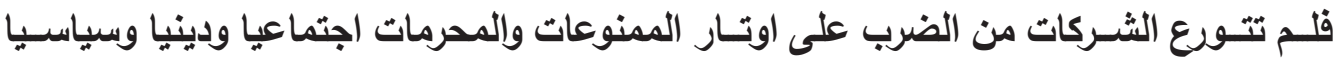

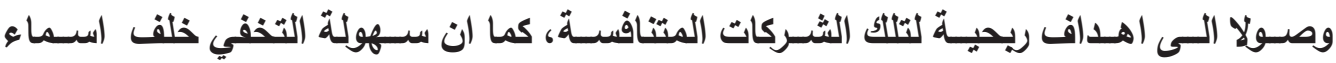

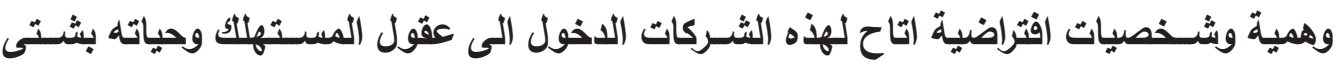
الطرق والوسـائل التـي تتيح للمتلقي الوصول اليها بســـولئة.

اخيـرا فـان مميـزات وخصائـص الفضــاء الالكترونـي تبقـى مجرد وسـيلة تسـويقية مادية

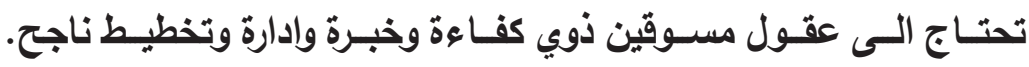

\section{الاستنتاجات و التوصيات}

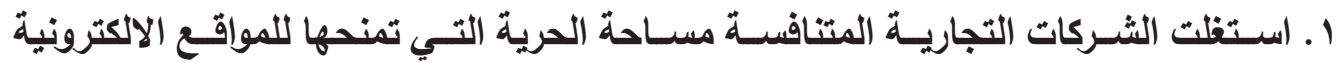

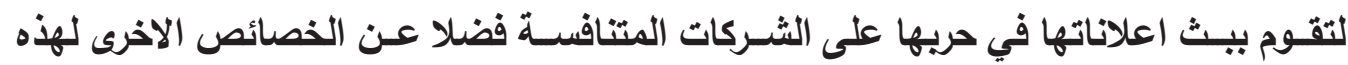




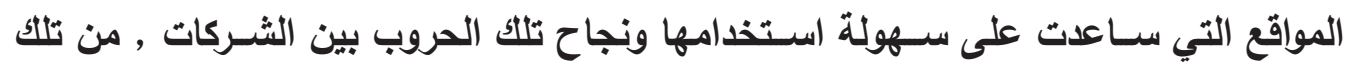

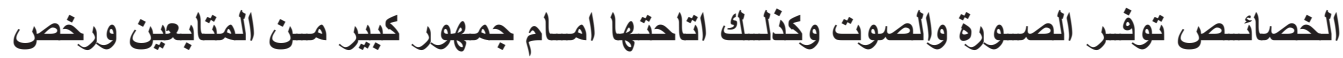

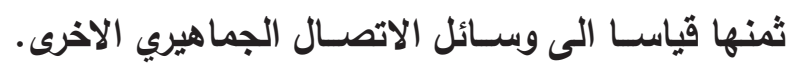

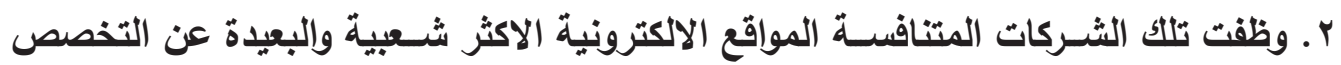
لضمان الوصول الى المستـلك العادي والبسـيط وذو الثقافة العلمية المتدنية.

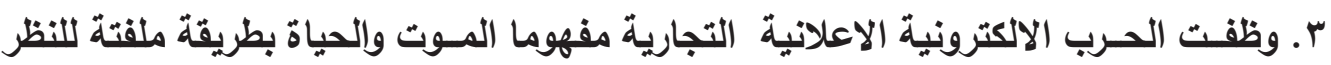
وياسـلوب ذكي مدعوم بالادلة والتجربة والصوبة الاعلية الصورة.

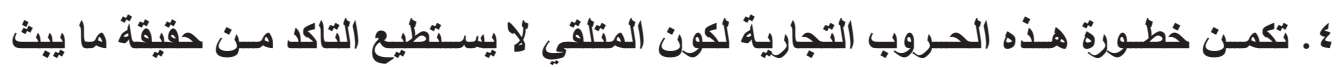

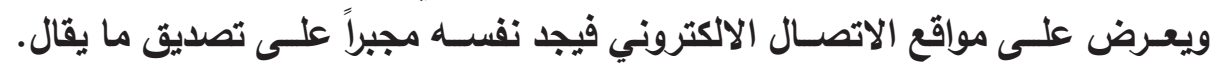

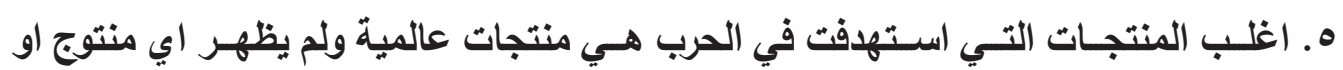

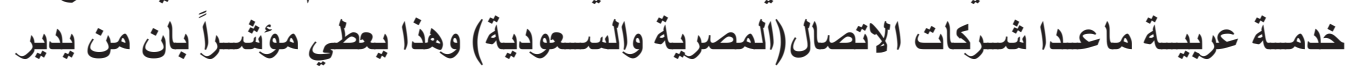

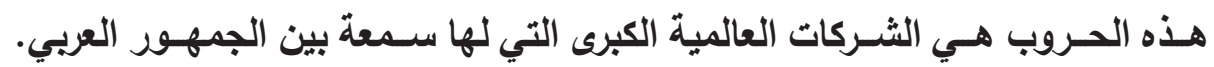

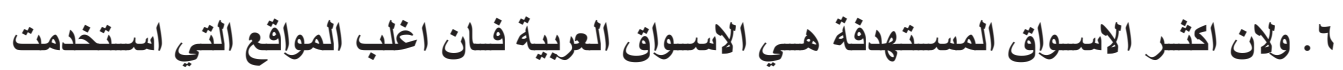
في الحـرب كانت مواقـع عربية.

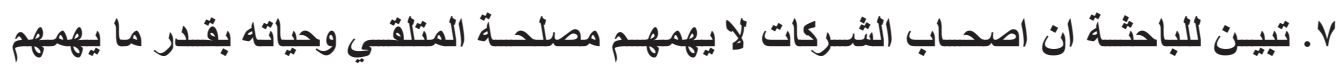

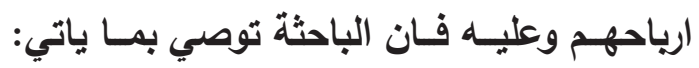
أ.حماية المستهلك العراقي من خلال وضع قوانين او تنظيم حملات توجيهية ارثــادية لتوعية

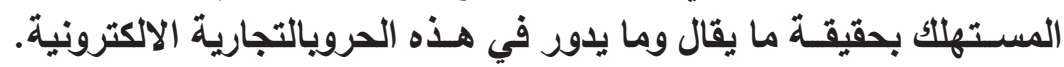
ب.مراقبة الاسواق المحلية ووضعها تحت سيطرة اجهزة الدولة الرقابية.

ملحق رقم (1)

يبين أهم المواقع الالكترونية التي استخدمتها الحرب الدعائية الالكترونية 1 ا موقع خبرني. r. r. موقع بنت جبيل

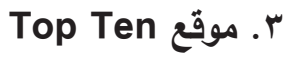
ع ـ قناة فضائية ماليزية ه. قاة LBC اللبنانية 7 . موقع طرائف 
v . موقع ثقافة وطرائف

^. ـ. موقع المتلقى العراقي الاسترالي

9. مدونة الدكتور محمد الصفي العيدي

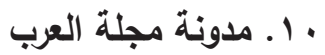

did not know info.blogs 11 . 1 مدونة r ا ا ـ موقع خواطر فضيلة الثيخ الشعراوي

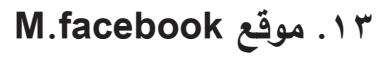
ك ا ـ موقع معلومة.نعم

ه 1 ـ موقع مونتي كارلو الدولية 1 ا 1 ـ موقع اللجنة الدولية للصيليب الاحمر الاولية ا I ا ـ موقع عالم المعرفة

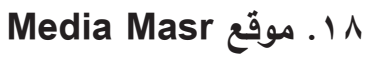

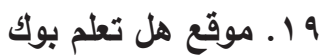
r.r. r. موقع ( بعد ما ننطيها)

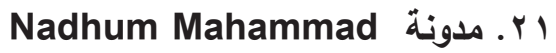
r r Y r. مدونة - مدونة

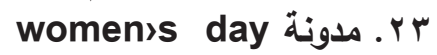
ع ז. ـ موقع سكاي نيوز

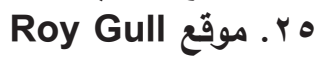

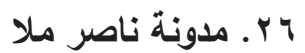

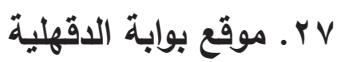

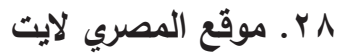

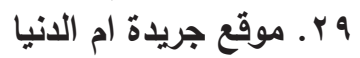

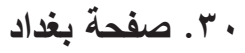

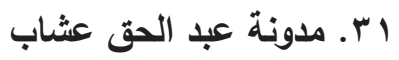

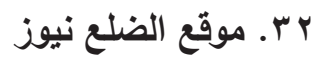

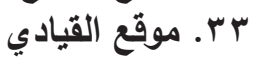
ع ب. موقع اخبار التقنية

\begin{tabular}{l|c} 
& مجلة الباحث الاعلامي| \\
\hline$\mu$ & العدد ( $1 \mu$
\end{tabular}


الهوامش

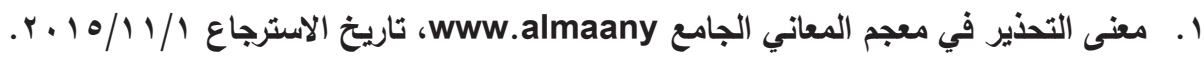
r . . معنى التبكيت في معجم المعاني الجامع، المصدر نفسه

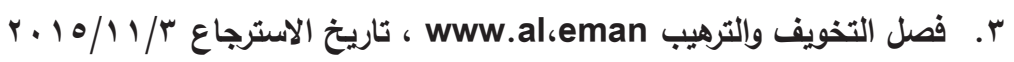
ع. ـ المصدر نفسه.

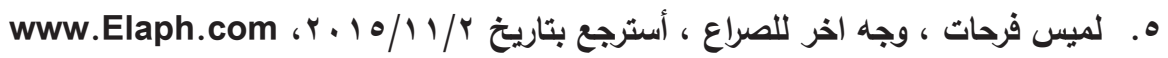

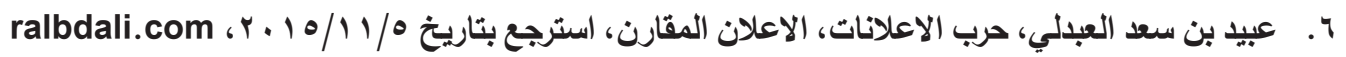

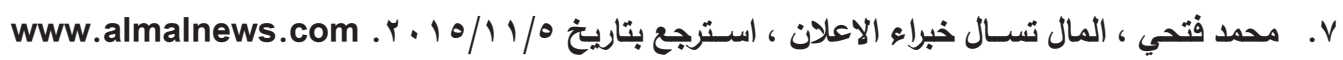

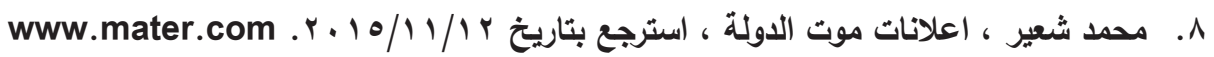

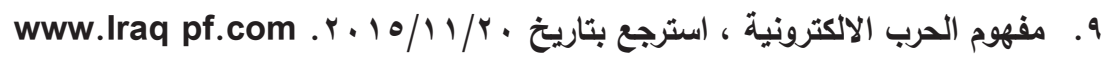

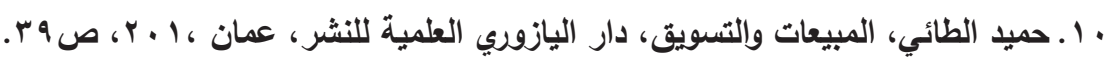

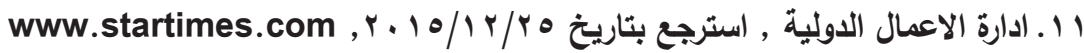
r ا ـ احمــ فــاروق رضـوان، الاتصـال والتســويق الاعلاني للخدمـات التجاريـة الريحية، دار الكتــاب الجامعة ،

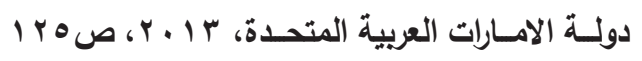

ب ا ـ احمد فاروق رضوان, الاتصال التسوسـيقي والاعلاني للخدمات التجارية الريحية , المصدر نفسـه, صع ب

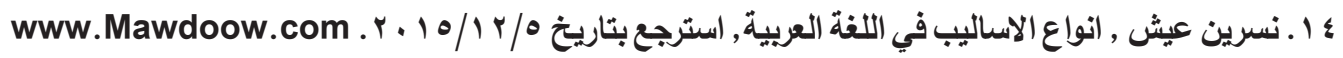

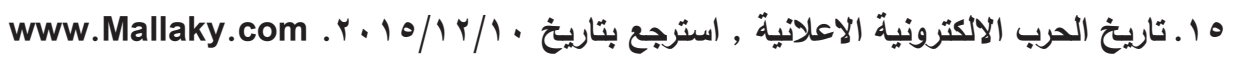

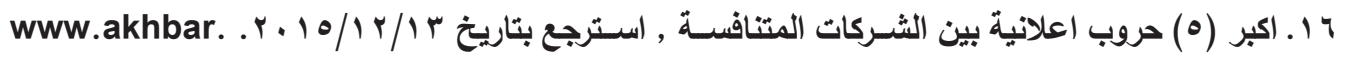
tech.com

V ا ـ اكبر (0) حروب اعلانية بين الشركات المتنافسة ,المصدر نفسه. 1 ا ـ موقع البوابة الاكتروني/حرب دعائية مشتعلة بين فودافون والاتصالات ww.dk.gate.com

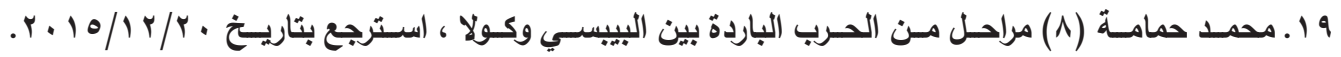
www.almaseyalyom.com

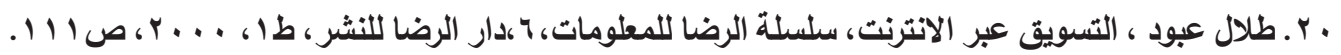

